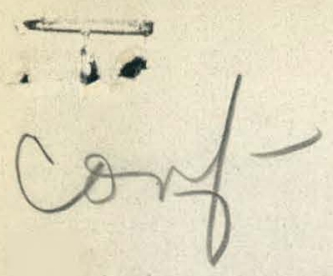

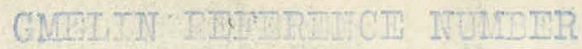

$63-202-9$

AT RF TECHNTQUE FOP PIASMA NUMEIER DENSITY MEASURIMMENP

by

F. W. Cramerd

CONF-363-12

\title{
International Symposium on
}

Plasma Phenomena and Measurement

San Diego, California

October 29-November 1, 1963

Internal Mernorandum

Contract $\operatorname{AT}(0)-3)-326-1$

M. I. Report No. 1087

October 1.963

$\left(\begin{array}{l}\text { To be presented at the IBde International } \\ \text { Symposium on Plasma Phenomena and Measure- } \\ \text { ment at Sen Diego, October } 1963 .\end{array}\right.$

Prac gublished by IEEE Iransactionsor

nuclear buience

Microwave Laboratory

W. V. Hansen Laboratories of Fhysick

Stanfora University

Stanford, California

\section{LEGAL NOTICE}

This report was prepared as an account of Government sponsored work. Netther the United States, nor the Commission, nor any person acting on behalf of the Commission:

A. Makes any warranty or representation, expressed or implied, with respect to the accuracy, completeness, or usefulness of the information contained in this report, or that the use
of any information, apparatus, method, or process disclosed in this report may of any Information, apparatus, method, or process disclosed in this report may not infringe Brity owned rights; or

B. Assumes any linbilities with respect to the use of, or for damages resulting from the of any information, apparatus, method, or process disclosed in this report.

ployee or contractor of the Commission, or employee of such contractor, to the exten em-

such employee or contractor of the Commission, or employee of such contractor prepares disseminates, or provides access to, any Information pursuant to his employment or contract

Facsimile Price $\$$

Microfilm Price \$

3.60
1131

Available from the

Office of Technical Services

Department of Commerce

Washington 25, D. C. 


\section{DISCLAIMER}

This report was prepared as an account of work sponsored by an agency of the United States Government. Neither the United States Government nor any agency Thereof, nor any of their employees, makes any warranty, express or implied, or assumes any legal liability or responsibility for the accuracy, completeness, or usefulness of any information, apparatus, product, or process disclosed, or represents that its use would not infringe privately owned rights. Reference herein to any specific commercial product, process, or service by trade name, trademark, manufacturer, or otherwise does not necessarily constitute or imply its endorsement, recommendation, or favoring by the United States Government or any agency thereof. The views and opinions of authors expressed herein do not necessarily state or reflect those of the United States Government or any agency thereof. 


\section{DISCLAIMER}

Portions of this document may be illegible in electronic image products. Images are produced from the best available original document. 
It j.s well-lenown that a cylindrjcal plasma column in a transverse rf electric fijejd is subject to a dipoje resonance. The Irequency at wich this occurs can be used to determine the averege electron density ecross the plaama section. This paper describes the experimental application of the technique to plasmas vith and without a confining exial static magnetic field, and gives theoretical curves to assist in rapid reduction of the data. Higher order multipole resonances cau also be exclted. The feasibility of applying these to determination of the numioer dencity prorile 16 discussed. 
Abstract.......................... 11

I. Introduction ...................... I

II. Theory of the Resonance. . . . . . . . . . . . . 4

A. The Effect of Electron-Neutral Collisions. . . . . . . 9

B. The Effect of a Static Axial Magnetic Fleld. . . . . . . 9

C. Effect of Nomuniform Density .............. 20

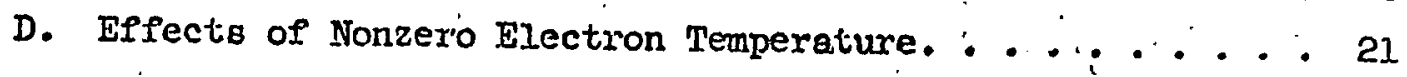

III. The Experimental Method................ 24

A. Observrations on Resonance Shape. . ... $\because \because . . . . .24$

B. Measurements with Static Magnetic Fields ......... . 27

C. Independent Measurements of Electrou Density : . . . . 27

D. Multipole Resonances .................. 27

E. Measurements on Fluctuating Discharges............ . . . 29

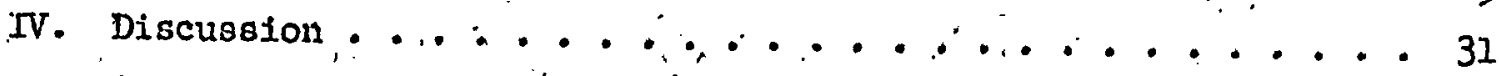

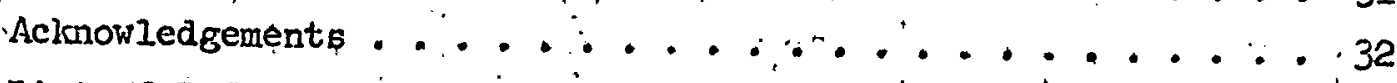

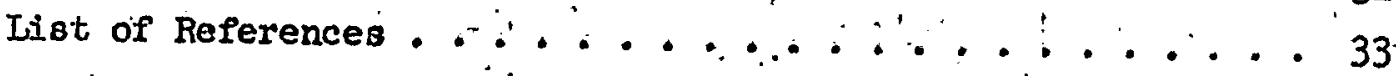


1. Djelectric rod perturbing a unjorm electric field. . . . 2

2. Iaeal cylinarical resonating system . . . . . . . . . 5

3. Variation of $h_{1}$ vith strip-line dimensions

(a) $\varepsilon_{1}=4.0 \ldots \ldots \ldots$

(b) $\varepsilon_{1}=4.5 \ldots \ldots \ldots \ldots \ldots$

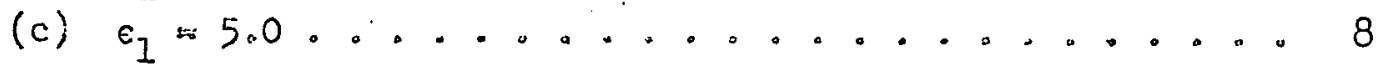

4. Variation of $k_{2}$ with strip-line amensions

(a) $\varepsilon_{1}=4.0 \ldots \ldots$

(b) $\varepsilon_{1}=4.5 \ldots \ldots . \ldots \ldots$

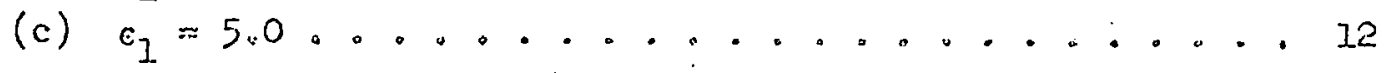

5. Variation of $\mathrm{is}_{3}$ with strip-line dimensions

(a) $\varepsilon_{2}=4.0 \ldots \ldots 13$

(b) $\varepsilon_{1}=4.5 \ldots \ldots \ldots \ldots$

(c) $\epsilon_{1}=5.0 \ldots \ldots \ldots$

6. Variation of $k_{4}$ vith strip-1ine dimensions

(a) $c_{1}=4.0 \ldots \ldots \ldots$

(b) $c_{1}=4.5 \ldots \ldots \ldots \ldots \ldots \ldots \ldots \ldots$

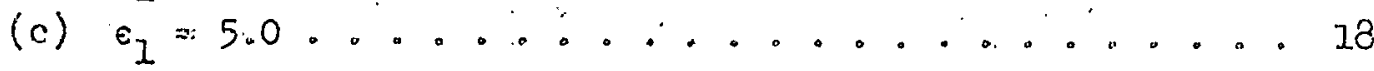

7. Varfation of $\left(k_{\text {eff }} / k_{I}\right)$ with $\left(a / \bar{\lambda}_{D}\right) \ldots \ldots . . . . . . .23$

8. Typical surip-line exciting system, and experimental circult. 25

9. Typical dipole $x \in$ sonance shapes............. . 26

10. Electrontes for cacjling muluipole rezonances......... 23

11. Measurement of fluctuating density components ........ 30 


\section{- J. INTRODUCTION}

Several rf techniques are evaliable for plasma electron density measurements, their ranges of application depending generally on the system dimensions and the electron density to be measured.. Some involve incasurements of vave propagation along or across the column, while others depend on perturbation by the plasws of the regonant frequency of a probing structure vithin it, or of a wicro- wave cavity surrounding the column. In this paper ve shall deal with a technique based on a dipole resonance of the plasme column. The way in which this occives can be understood from consideration of the idealized system shown in Pig. $T$. If the rod is of uniform, 1cotropic, dielectric material of permittivity $\epsilon^{\prime}$, relative to free space, then the electr1c field Ins1de, $\mathbb{E}_{1}$; ls relatied to that outside at Infinity, $\mathrm{E}_{0}$, by the expression, ${ }^{1}$

$$
E_{1}=\frac{2 E_{0}}{1+\epsilon^{\prime}}
$$

If the dielectric of interest is the positive column of a. gas discharge, we may substitute the value of ' $\epsilon^{\prime}$ approprlate to a plesma. Neglecting the dampinj antect of collisions, and assuming a cold plasma, this is

$$
\varepsilon=1-\frac{\omega_{p}^{2}}{\omega^{2}}
$$

where $\omega$ is the applied frequency and $\omega_{p}$ is the electron plasme frequency ajon by

$$
\omega_{p}^{2}=\frac{n e^{2}}{\epsilon_{0}^{m}} \quad \because \quad \because \quad \because
$$

Here $n$ is the electron number denolty, es is the electronic charge, $n$. 16 the electronic mass and $\epsilon_{0}^{\prime}$, is the permittivity of 'free cpace- 


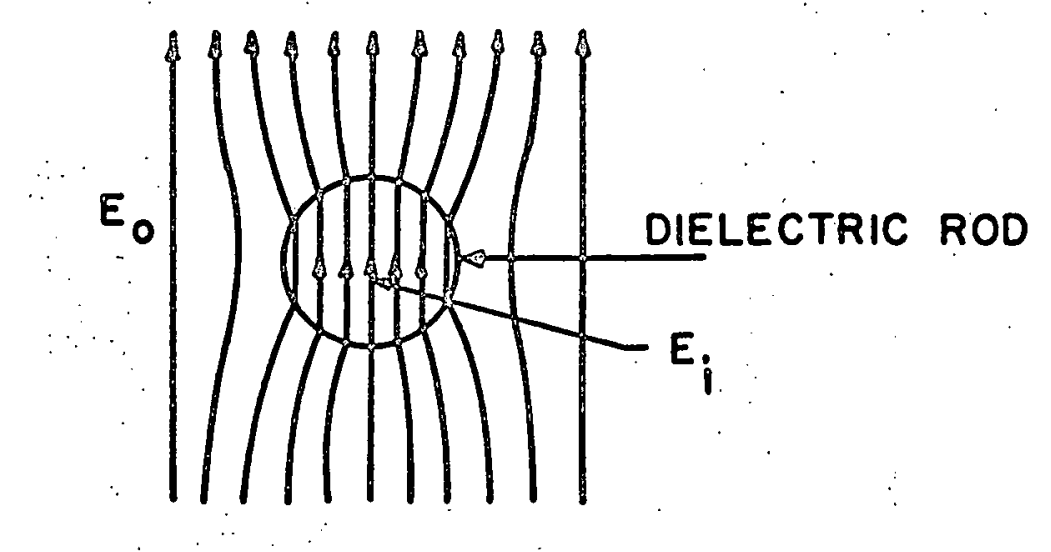

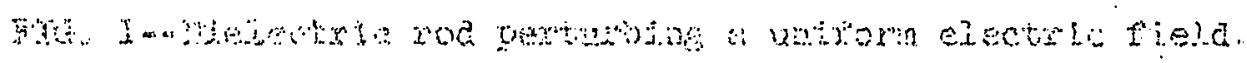


After oubstitution of Eq. (2) In Eq. (1), we note that there wjll be a resonance Wien

$$
\omega_{1}^{2}=\frac{\omega_{p}^{2}}{2}
$$

where $\omega_{1}$ is the dipole resonant frequency. This "is the basic dipole resonance effect first described by Tonks, ${ }^{2}$ and by Herlofson. ${ }^{3}$. Physjealiy, the resonnee occurs between the Pree-space capacitance and the inductive component of plasme. impedance due to inertia of the electroni.

Strjcily, the analysis leading to Eq. (lf) is incorrect oince the quasistatic. approximation cennot apply at nonzero frequency in an Infinite system. Nevertheless, ve might expect the anelysis to predict substantially the correct resonant irequemcy.. If the free-space. wavelength 18 'long compared to the dimensions of the region strongly perturbed by the presence of the column. Another assumption which is not physically coriect 16, that the column 1 s suspended alone in free spece; the erfecti of the glass tube surrounding it should be taken fnto account. In section II ve shall deal vith the modiflcations requixed to the simplified onalysio to talie into account such factors as tube and electrode geonetry; nonuniform electron density, noniero electron temperature, electron-heutzal collistons, and the presence of a static axial magnetic field.

The use of the dipole resonance effect as a diagnostic for electron density measurement is attrective in the range where propagation and cavity perturbaition techniques are uswally applied. The resonance can be excited by a circular stripline system, which is more easily construicted than a microvave cavity, and which is used at much lorer frequencies. 'The resolution of density variations along the tube axis is considerably greater than thet of propegation measuremenis, which usually require a length of substantially unfform column consfderably longer than the wiath of a strip-1ine exciting system. It will be noted, also, that the dipole resonence occurs only in the presence of the plasma, so that if' number density rluctuations are occurring, the proportionate changes in the resonent irequency are much greatex than in that of a resonant cavity. Thip. means that fluctuating alscharges may be more easily studied with the dipole resonance method.

It is the purpose of this paper to provide a lisey to the analyaes bearing on the dipole resonance phenomena and to the related experimental work, and in doins so, derine the conditions under vhich" it may be most readily applied. 


\section{J.I. THEORY OT THE RESONANCE}

The ncaificationo to $\mathrm{Eq}$. (4) demanded by a prectical set-up can be separatea into two parto; those dependent on the region external to the plasma, and those associaced with the plasme itself. If the exciting electrode dimensions are small compared to a Pree-space vavelength of the applied Irequency, the quasistatic assumption is accurate 4,5 and, wili allow us to reduce the problem in the region external to the plasma to the solution of 'Laplace's equation. In this worls, we shall be interested in the cylindrical system shown in Fig. 2a: for this case, Eq. (4t) becomes 6,7 ,

$$
\omega_{1}^{2}=\frac{\omega_{p}^{2}}{k_{1}}
$$

The geometrical constant, $\mathrm{k}_{\mathrm{i}}$. $\mathrm{i}$ s. obtained by puiting $\mathrm{m} ; 1$ in the expression

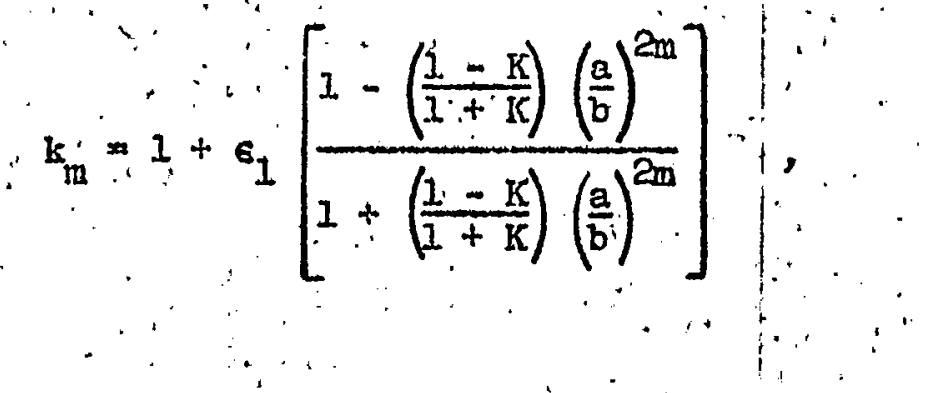

where is te Glven by

$$
K=-\left(\frac{1+\left(\frac{b}{c}\right)^{2 n 1}}{1-\left(\frac{b}{c}\right)^{2 m}}\right):
$$

In these expressions, $\epsilon_{1}$ is the relative,permitivity of the gless, and $a, b$, and $c$ sxe, respectively, the internsi end external radil of the glasa tube, and the raclius of the exciting electrodes: Most comercial glasses and guartz have $\epsilon_{1}$ in the range $4-5^{\circ}$. Comprated values of $k_{1}$ are shown in FiB. 3 for this range. 


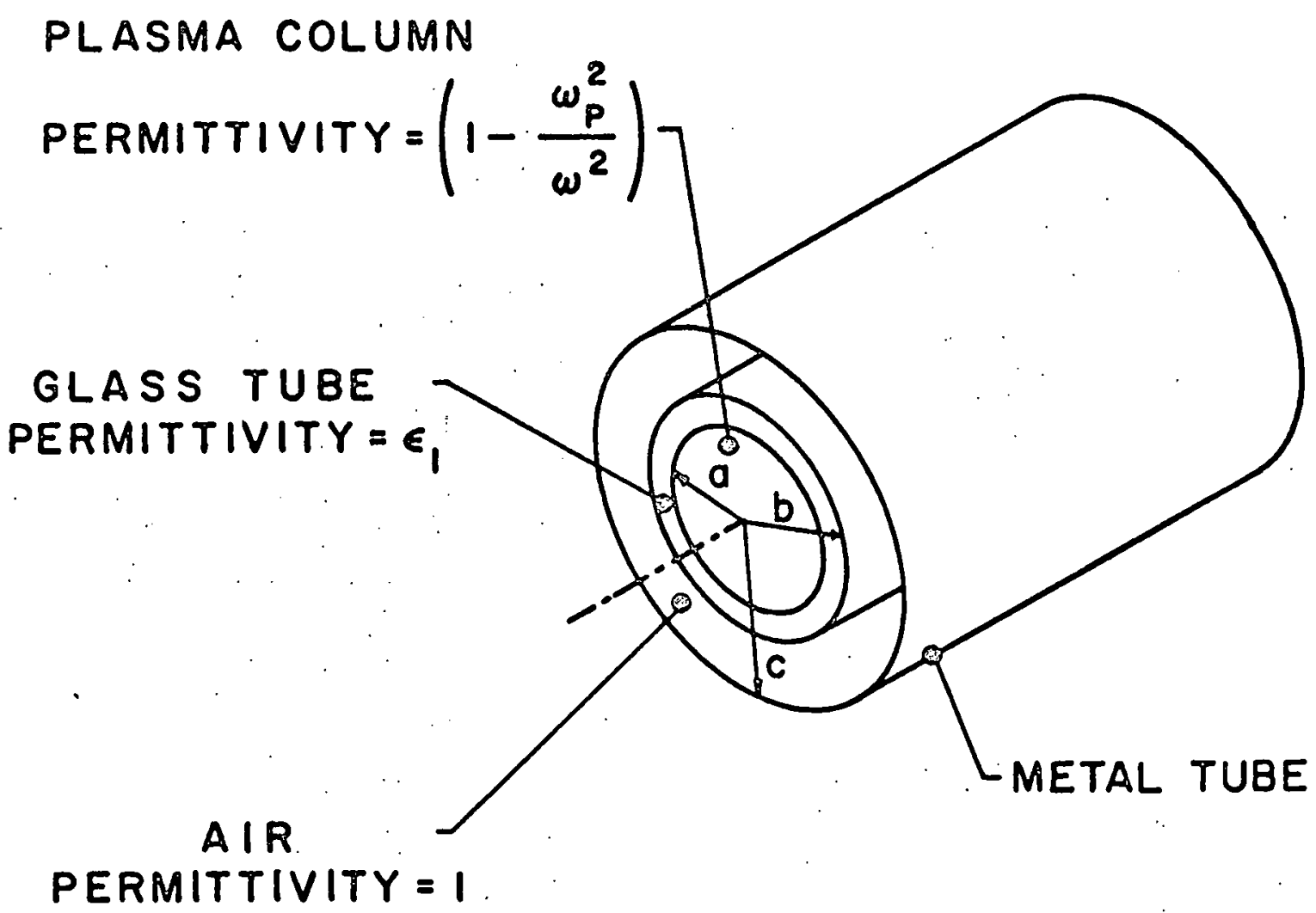

(a) GEOMETRY

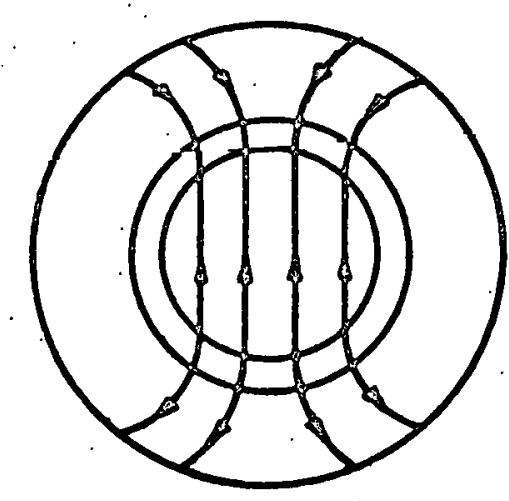

(b) ELECTRIC FIELD DISTRIBUTION

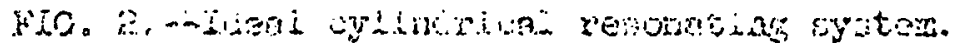




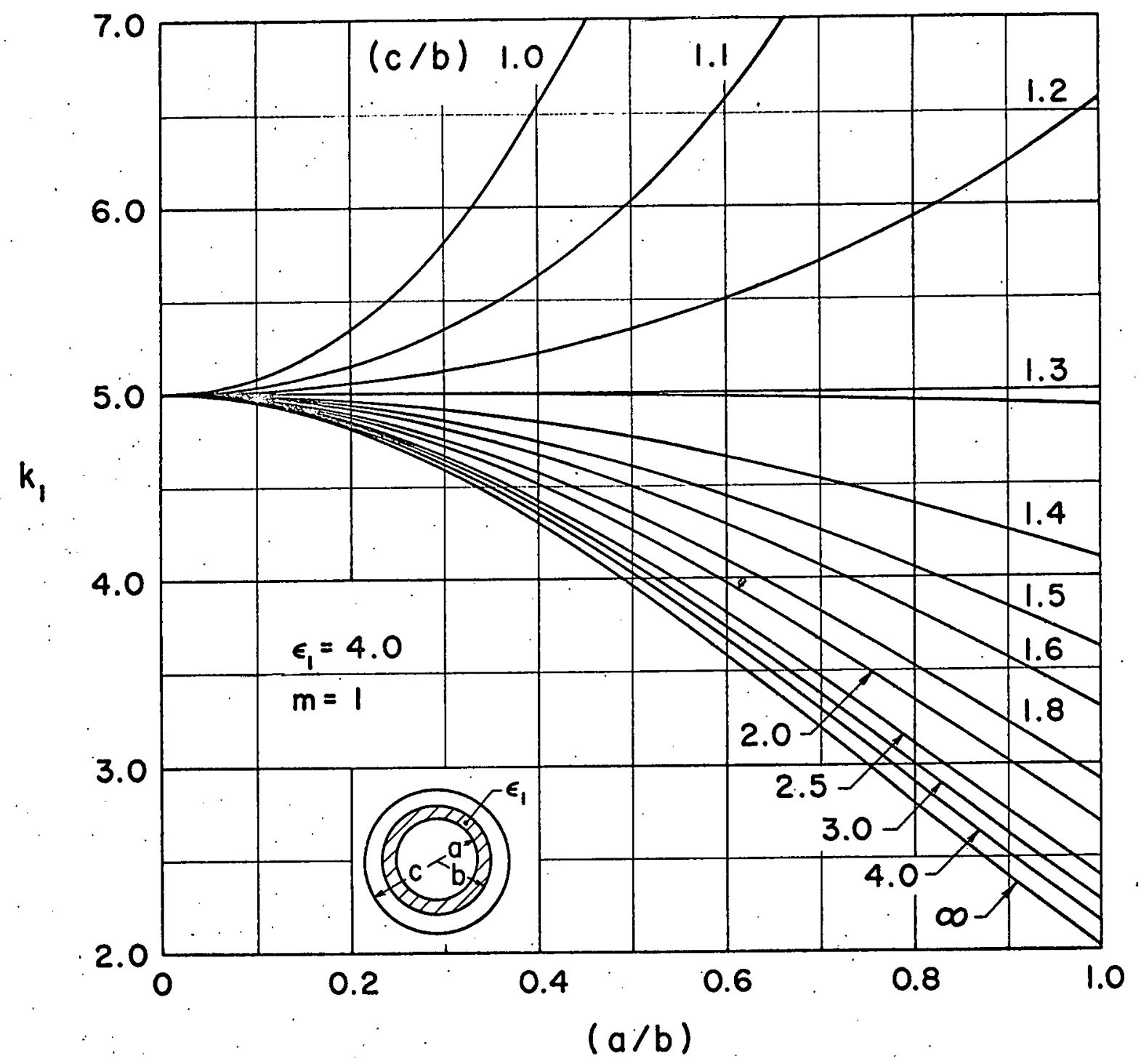

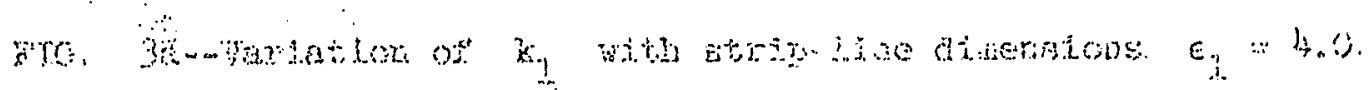




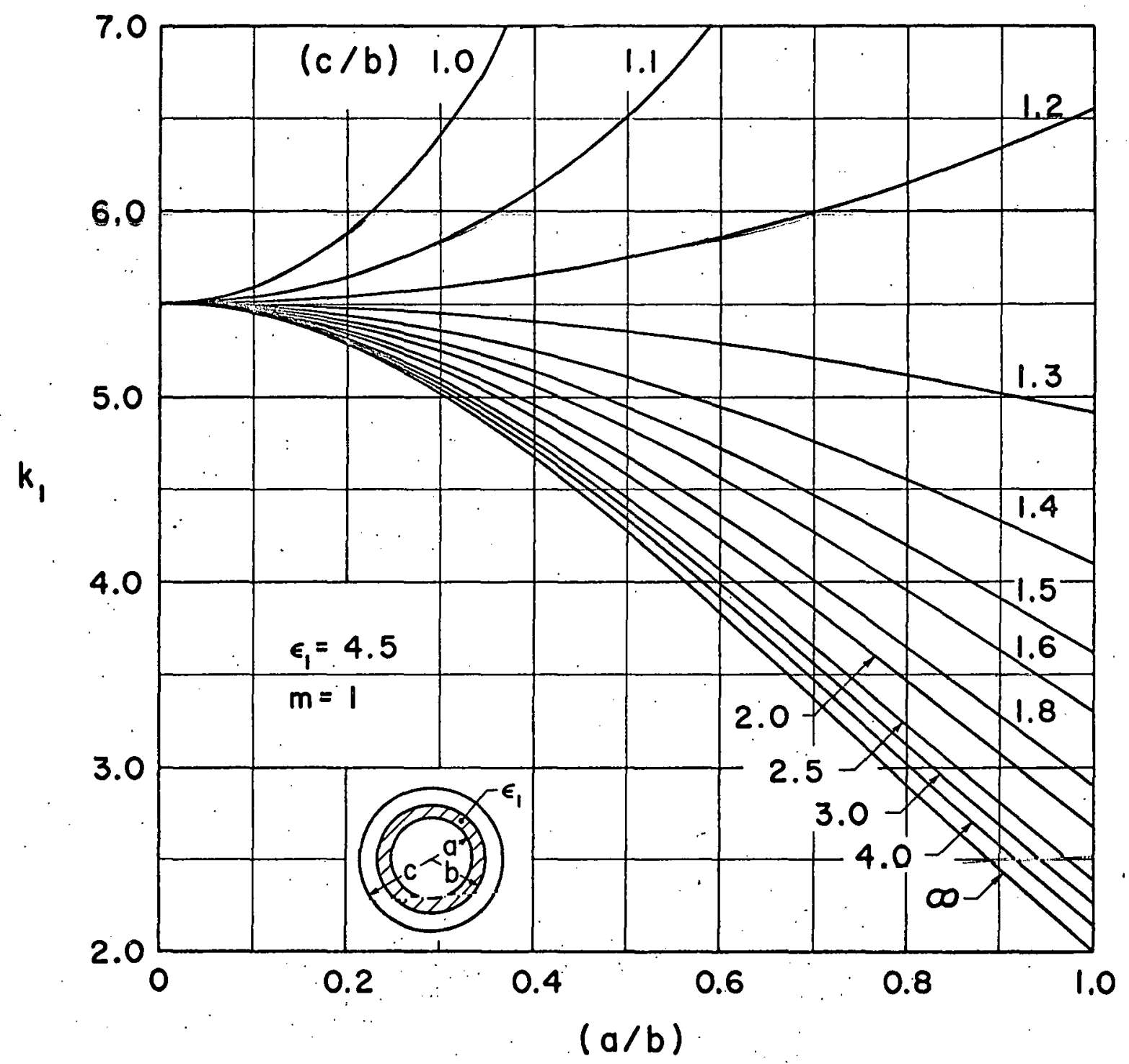

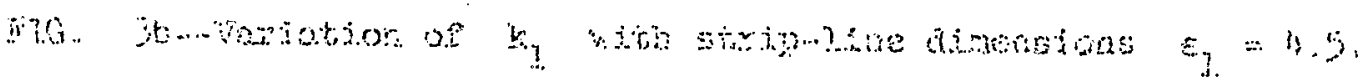




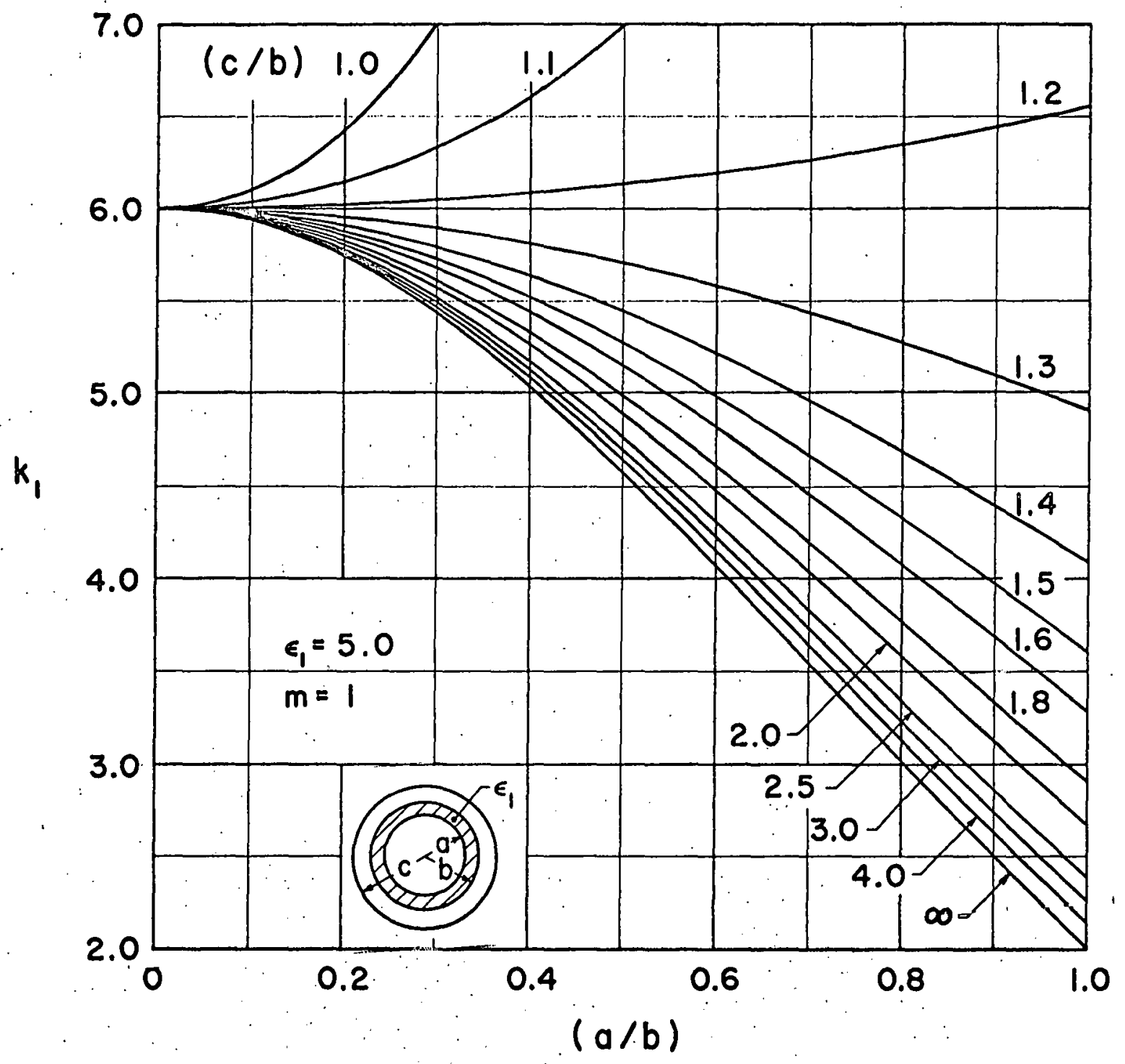

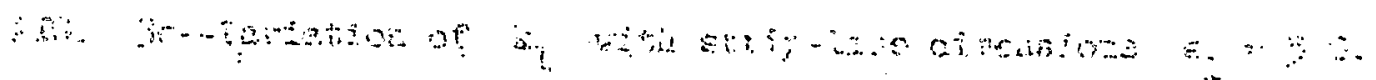


It is worth noting at this point that the fleld configuration of the dipole moxic sliom in Fig. ab is not the only one possiblo. Bj.gher-order multipole nodes can be excited. In the infinite system of Fig. J. these axe degenerate, but the presence of a surrounding glass tube, or of nonuniform electron density, renoves this degenexacy. We sholl return to these moles later in our discussion of electron densjty proflile mearements. Figures 4, 5, and 6 give computed velues of ir for these modes.

The analysis of the resonance has been extended to hollow discharges, ard sliows that cplititing of the resonance should occur 8,9 This has been checked experimcntally. ${ }^{8}$ A similar effect has been predicted and observed for solid elliptical plosmen columing. 10,1.1

We now turn to consideration of the assumption concerning the plasma column, and the nacessary maditlications to $\mathbb{E q}$. (5) if they are'relaxed.

A. TRE EHTECT OF TLECTRON-NEURRAL COLTISTONS:

It has been shown that the $Q$ of the resonance $1 \mathrm{~s}$ given by $(\omega / v)$ wiere $v$ is the electron-neutral collision frequency. 7 For the technique to be of valle: tre will nomalily work under condltions of electron density and neutral ges pressine such that $\theta$ is at least 10 . The dipole resonent frequency vill then be shifted by about $0.3 \%$ so that Eq. (5) will still apply to' a very close approximation.

\section{B. THE EFETCT OT A STATIC AXIAI, MAGNTTIC FIZLD}

If a megnetic field, B , is applied to the colmn, the relative pernittivity of the plesma is no longer isotroplc, but becomes a tencor quantity. In the analyojs, this difficulty can be overcome; in the case of an axtal magnet1c field, by resolvinis the electric iield tnto two equal counter-rotating components. The right-hand. polarized component rotates in the same sense as the electrons. In the nagnetic field ? and has a relative permittivity given by 


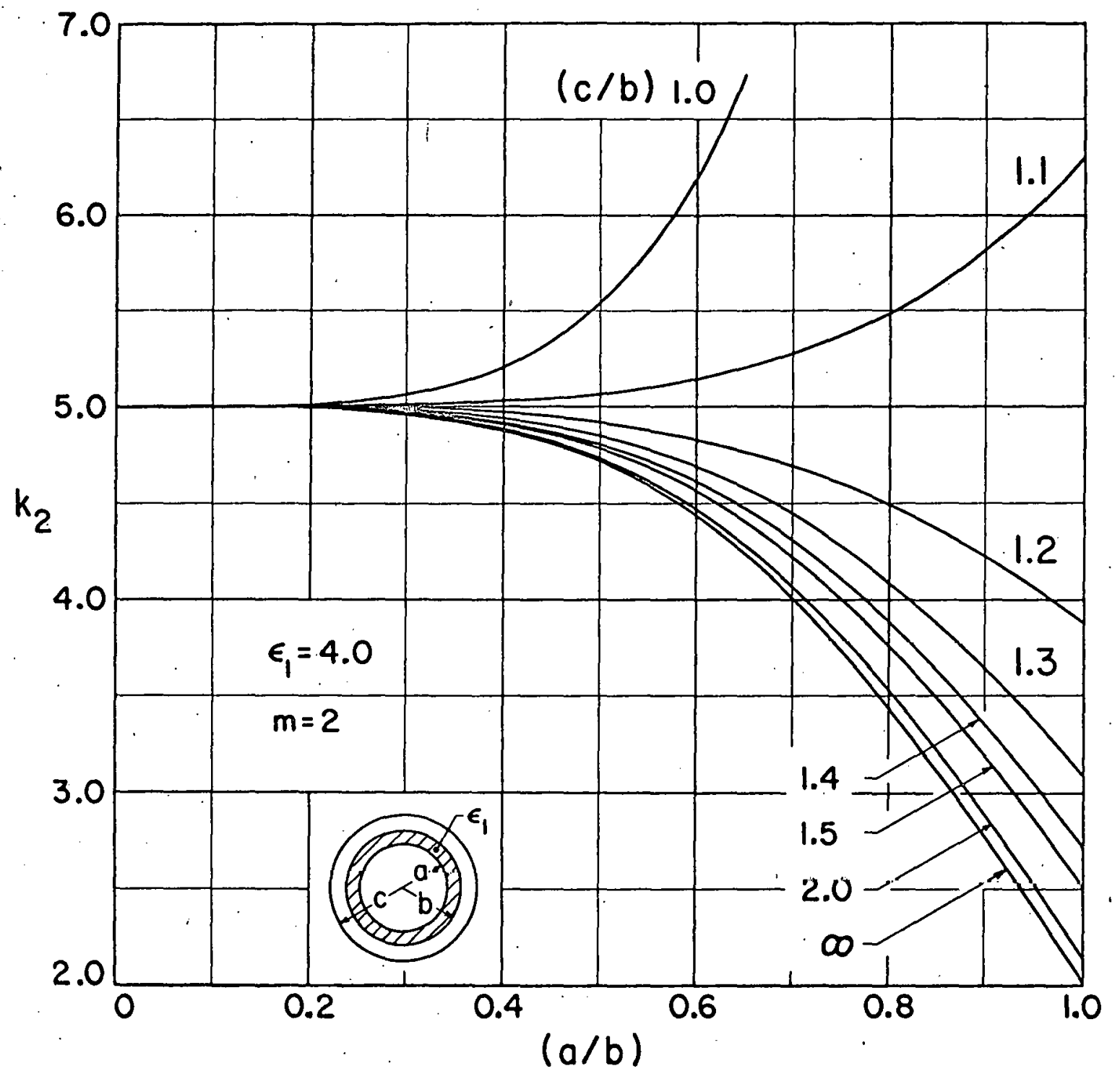

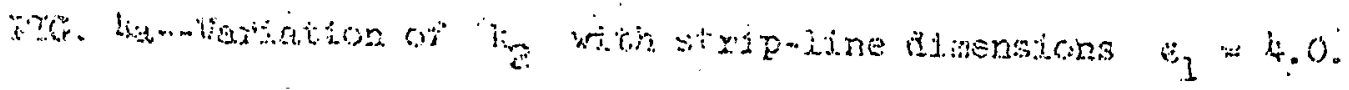




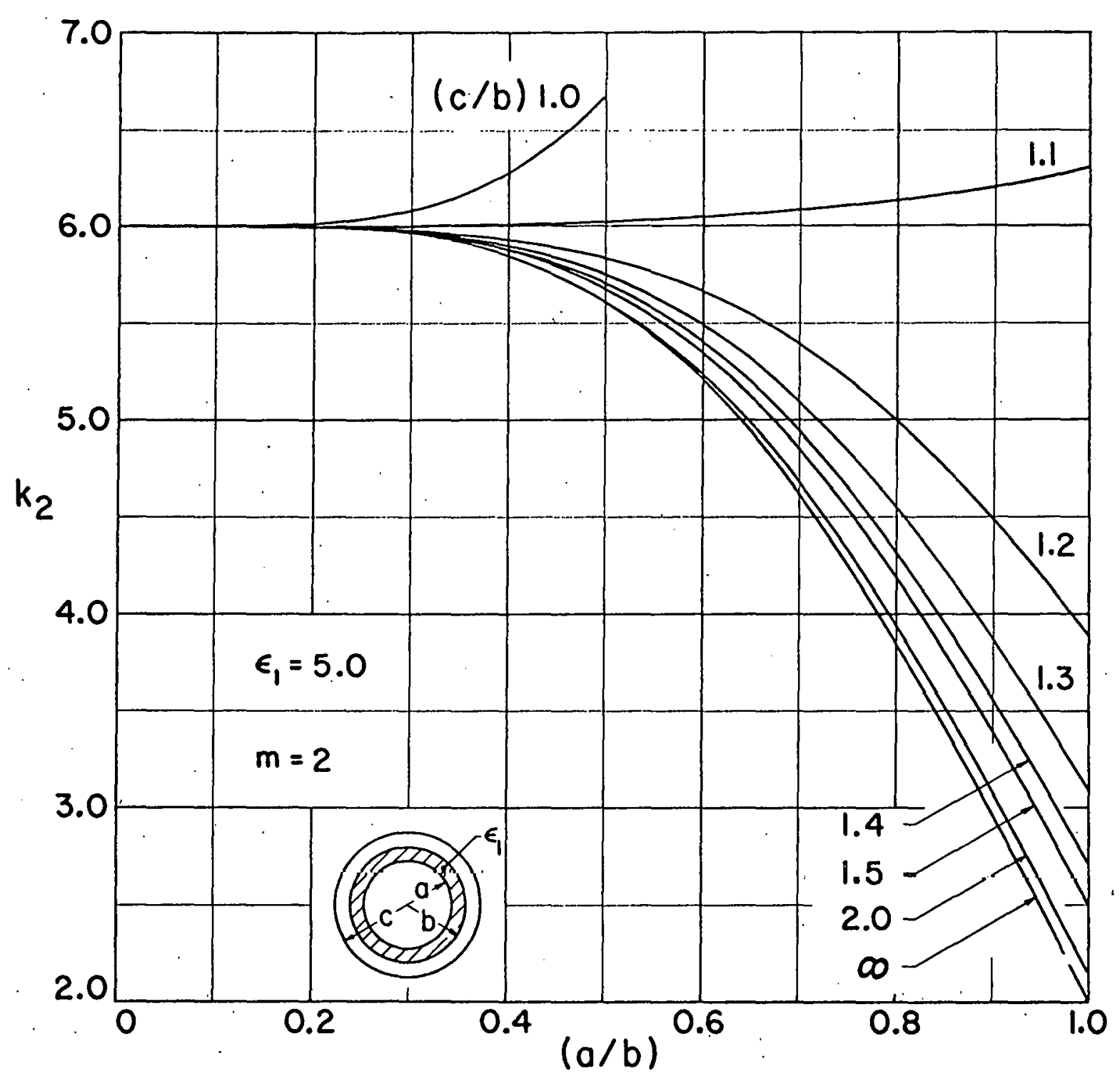

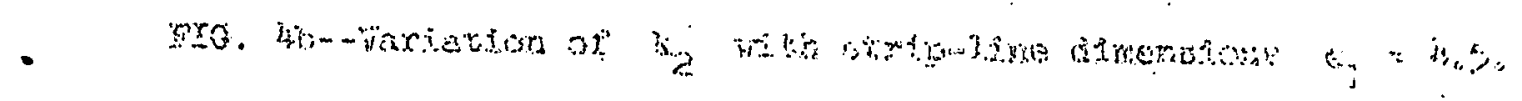
$-3$. 


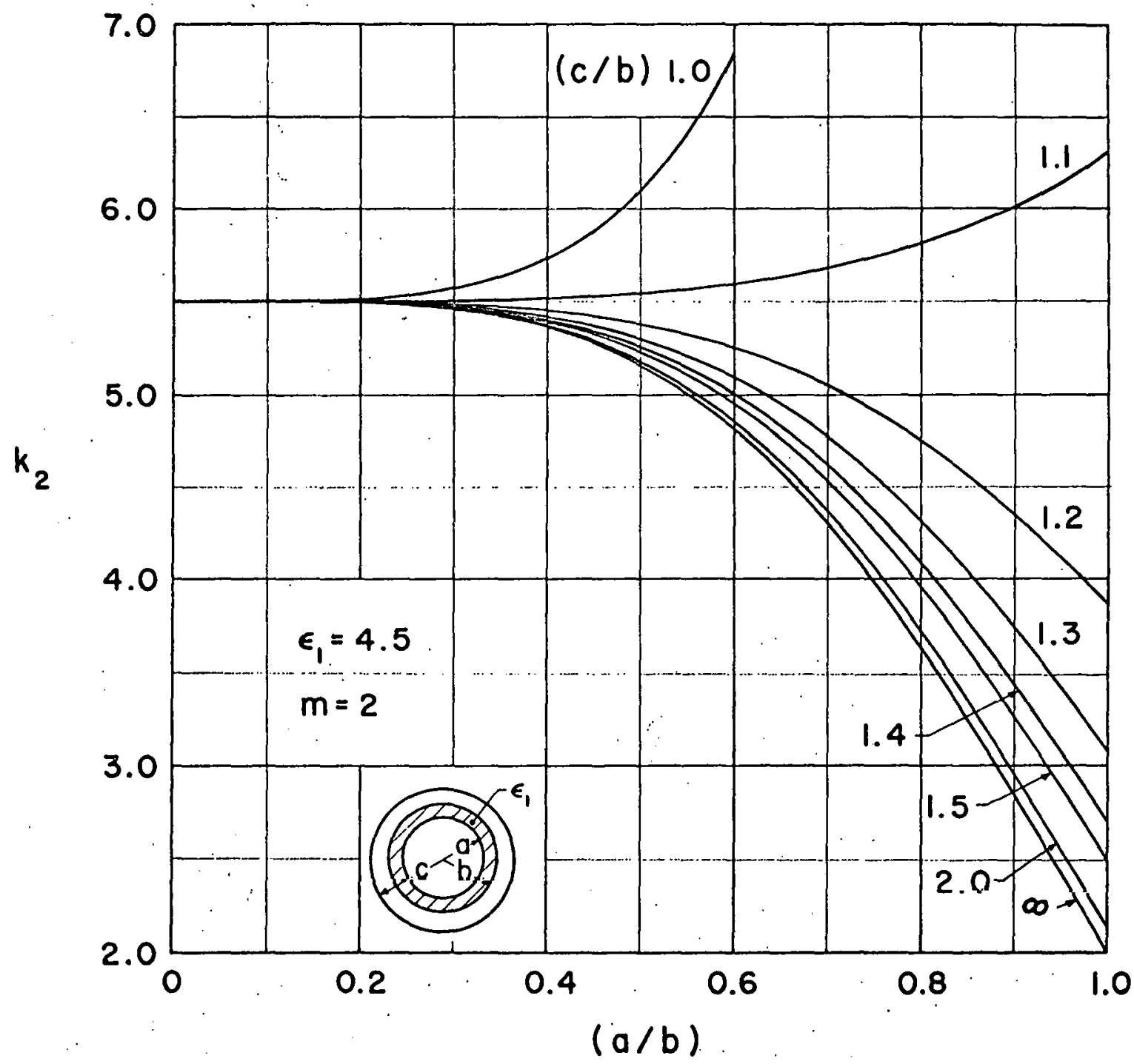

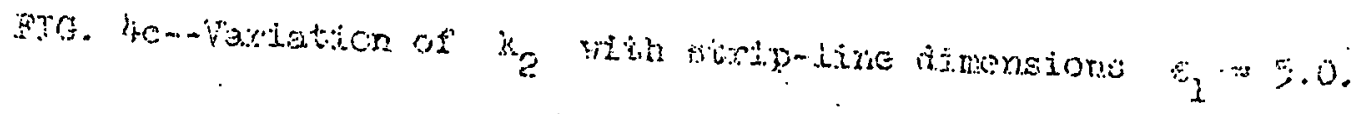




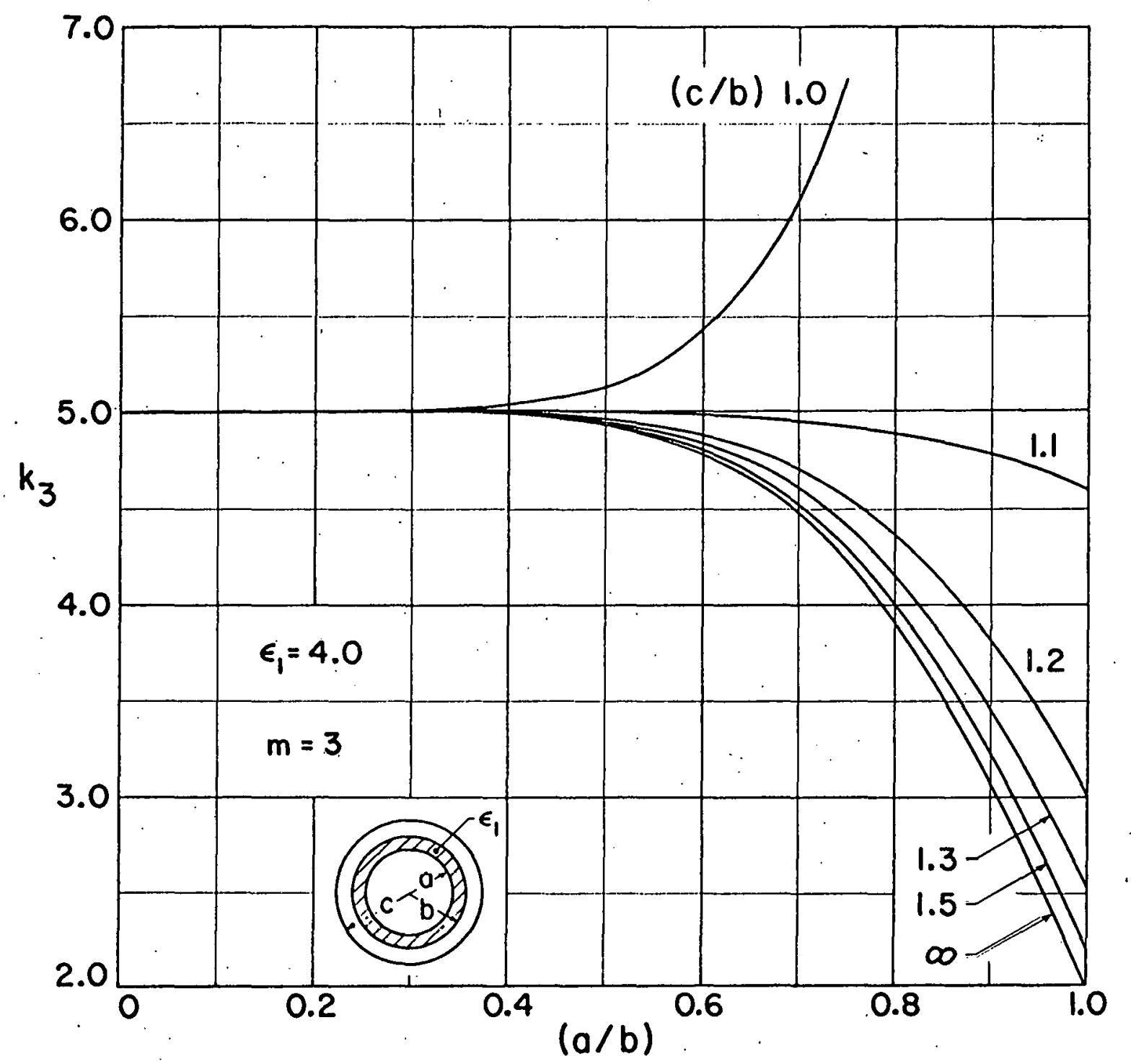

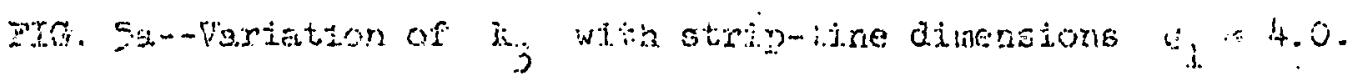




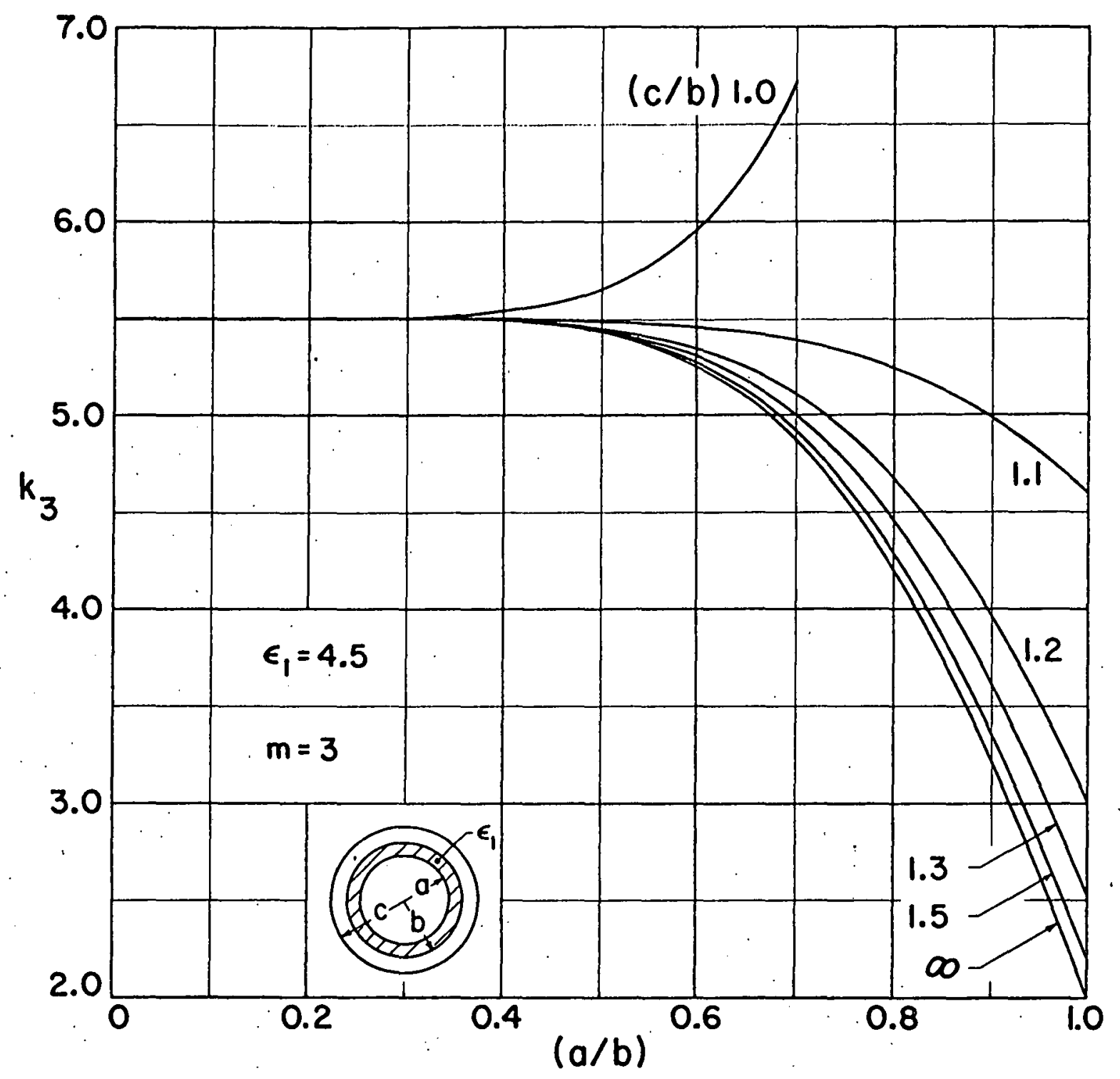

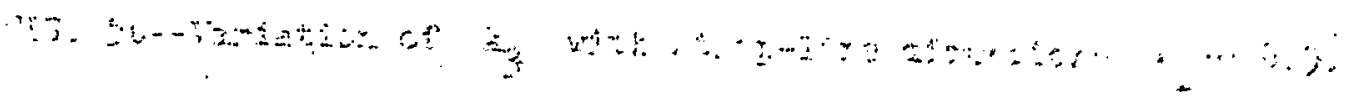




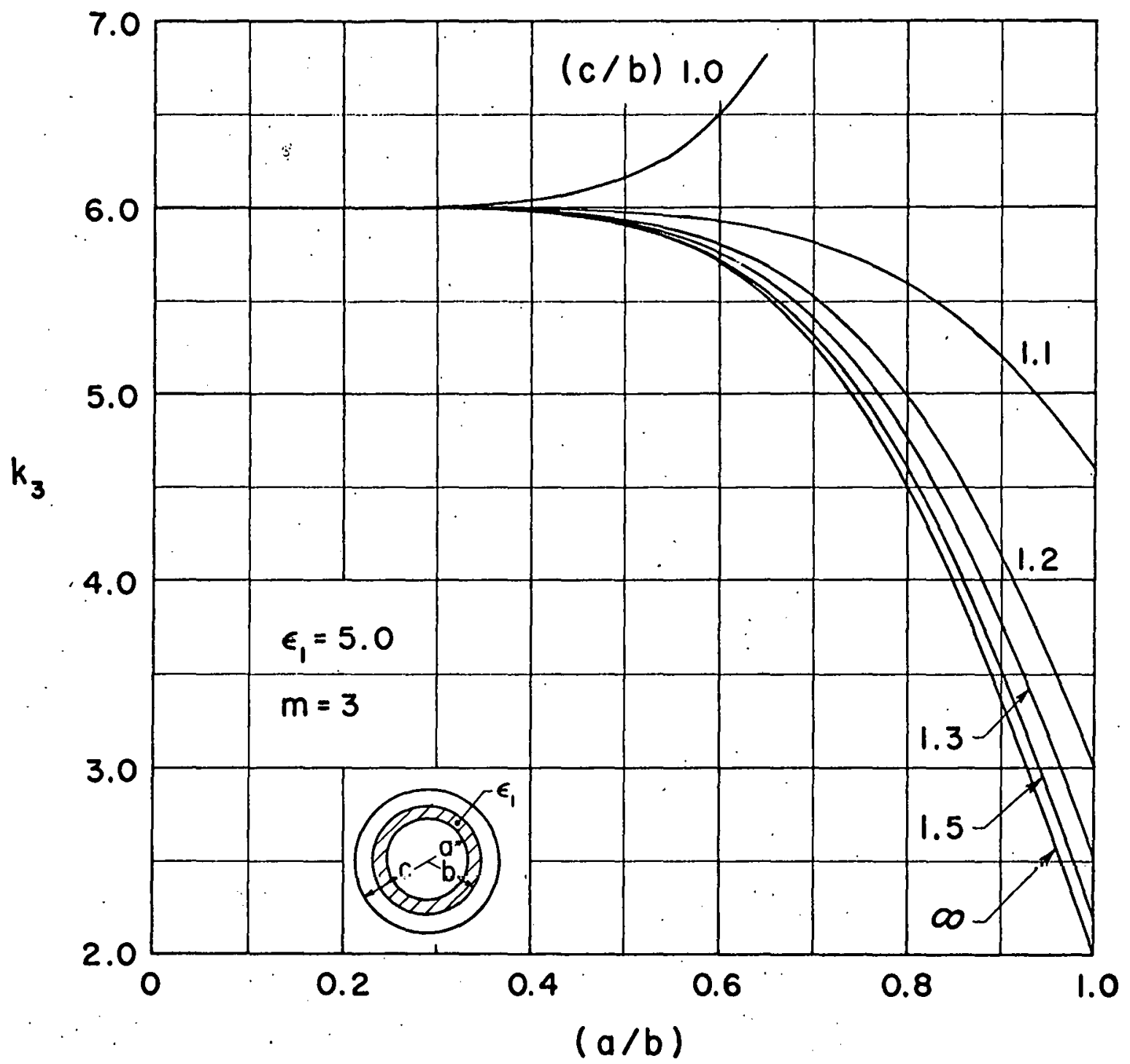

\% 


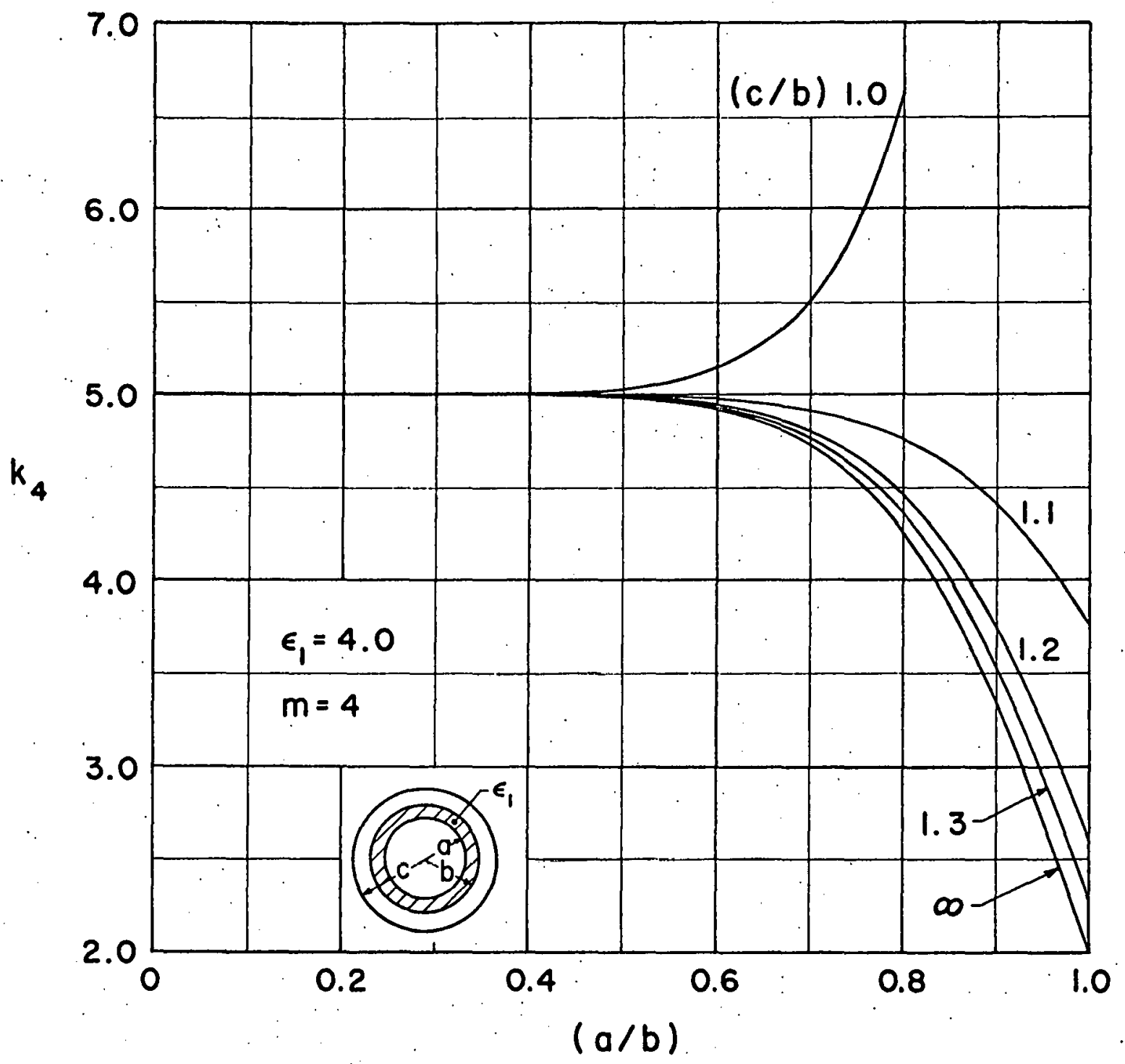

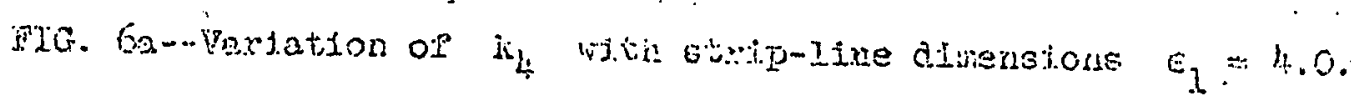




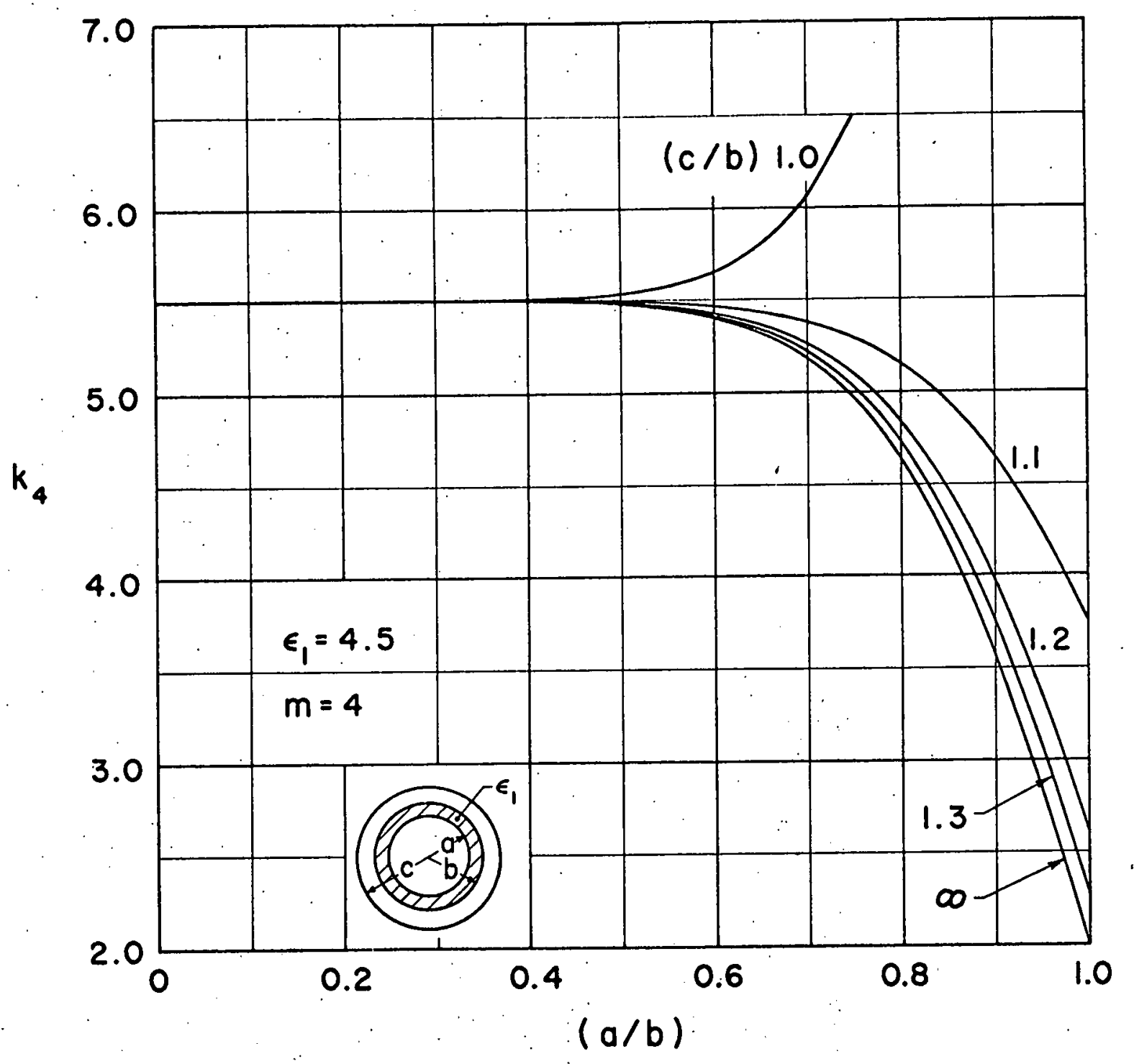

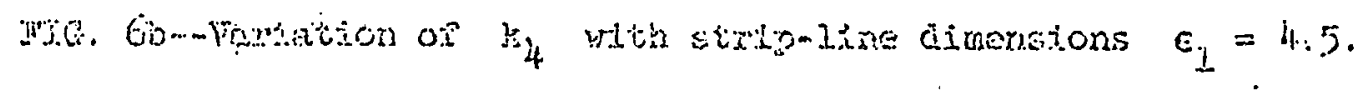




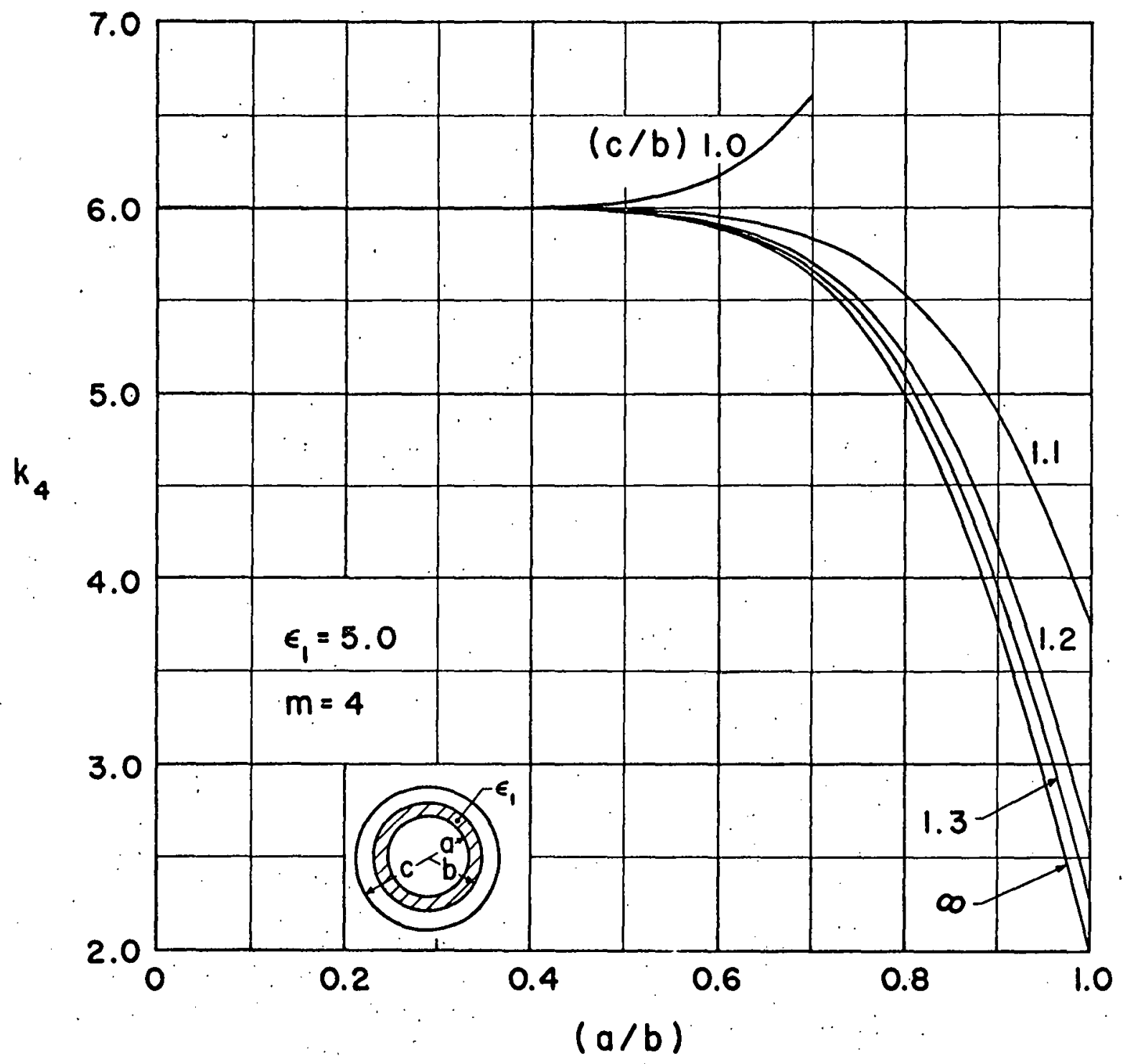

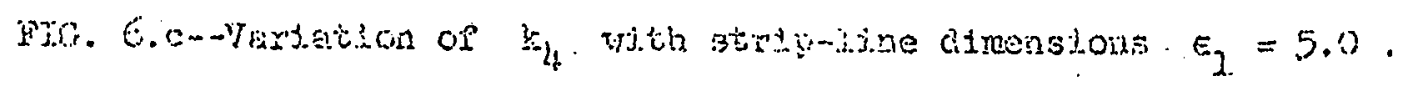


where $\omega_{c}$ is the electron cyclotron frequency glven by

$$
\omega_{c}=\frac{e B}{m}
$$

The left-hand polarized component hes relative permittivity

$$
\epsilon_{i}^{\prime}=1-\frac{\omega_{p}^{2}}{\omega\left(\omega+\omega_{c}\right)}
$$

.1

There are now tiro alpole resonant frequencles $\omega_{R}$ and $w_{L}$ in the rotating coordinate systens glven by, the modified forms on Eq. (5):

and

$$
w_{R}\left(\alpha_{R_{1}}-\omega_{c}\right)=\frac{\omega_{p}^{2}}{k_{1}} .
$$

These are equivilent to

$$
\omega_{L}\left(\omega_{L}+\omega_{c}\right)=\frac{\omega_{p}^{2}}{k_{1}}
$$

$$
\omega_{R}-\omega_{L}=\omega_{c} \cdot
$$

and

$$
\omega_{R} \omega_{L}=\frac{\omega_{p}^{2}}{k_{L}}
$$

This implies that the splitting increases alrectly with $\omega_{c}$, and that the density measurcment depends on the product of the two resonant frequencles. 


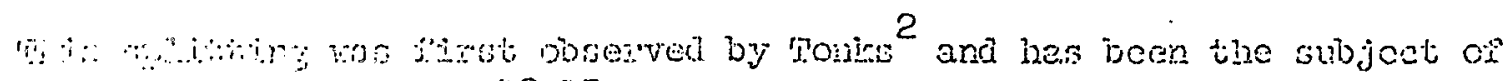

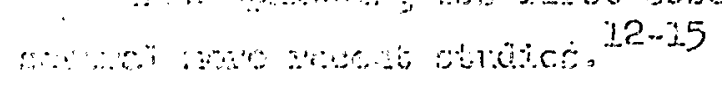

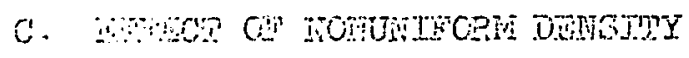

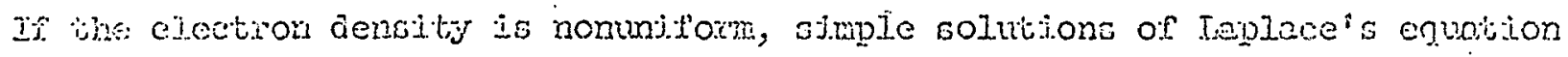
do not satisyy the conditions bithin the plasma. We wast solve the equation

$$
\nabla \cdot\left(1-\frac{\omega_{0}^{2}}{\omega^{2}}\right) \nabla_{1}=0
$$

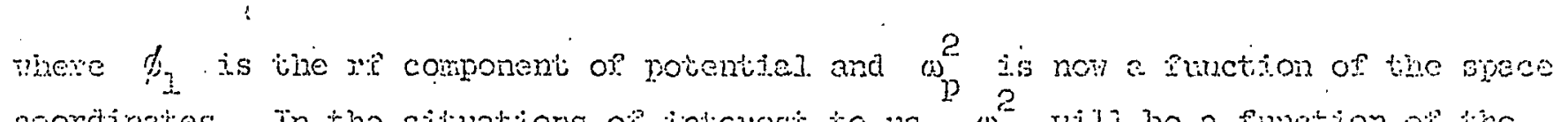

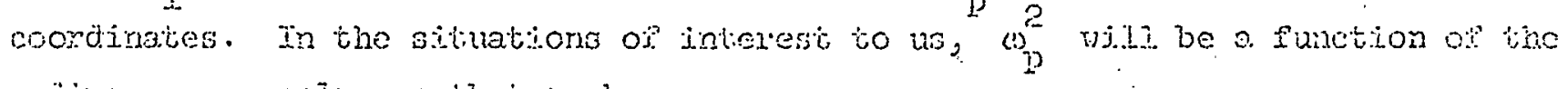
Iejius, $x$, onity, so that we have

$$
\mathrm{cis}_{\mathrm{p}}^{2}=\mathrm{i}_{\mathrm{j} \mathrm{C}}^{2} \mathrm{2}^{2}
$$

where wo is the local plasie frequency on the aris, and $f$ is a fuldion of $x$.

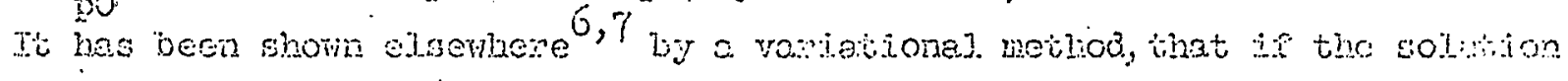

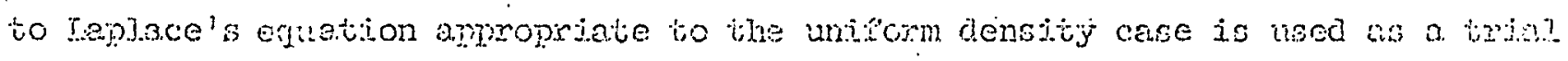
function in the determination of a mitipolo resonent finequeney, the Jerulting orpersitom is

$$
\omega_{i n}^{2}=\frac{1}{k} \int_{0}^{j} \omega_{p}^{2} \frac{a}{d x}\left(x^{2 n}\right) d x
$$

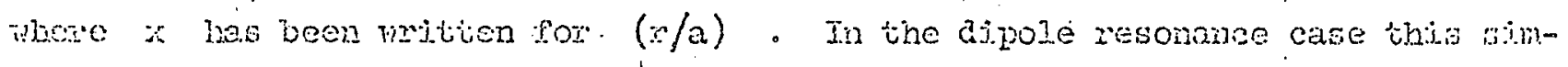
Ditifics to

$$
w_{1}^{2}=\frac{w^{2}}{k_{3}},
$$

nheve $i_{p}^{2}$ is dependent on the averoge eleaton density ecross the acotion. 


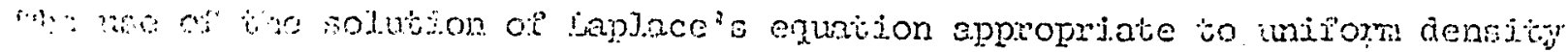

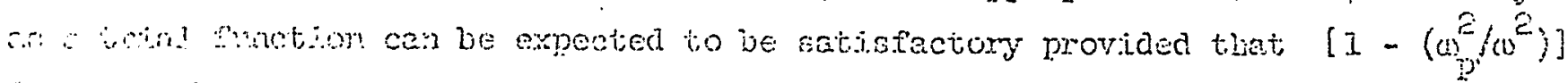

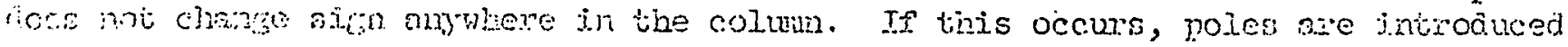
into the excot colution for the potential end a radically different trial function is nealed. Frysicaliy, such poles rill not exist, of course, due to erfecte weh at nomero electron temperature. To assess the exror involved sn using Eq. (18), these aspects must be exanined further.

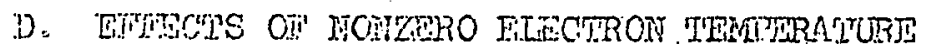

It: a morodymamic description of the plasma is used, the modified form of Eq: (15) cen bas shown to be 16,17

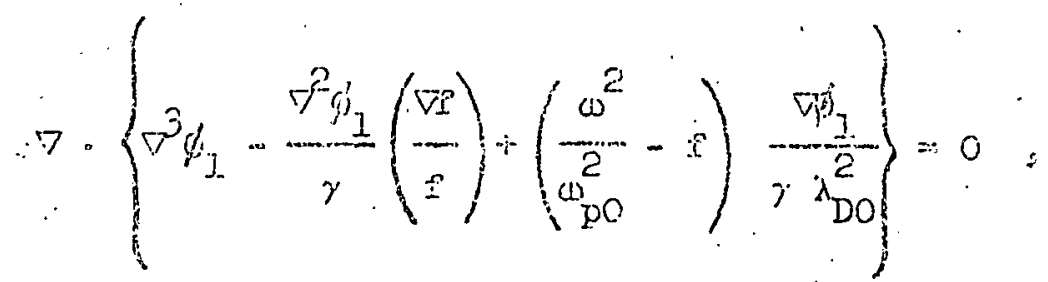

Where $\lambda_{\text {po }}$ is the local. Debye leagth at the tube axis and y is the conjpession constants for bhe ejectron ges.

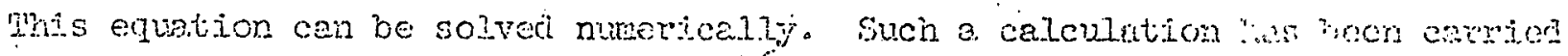

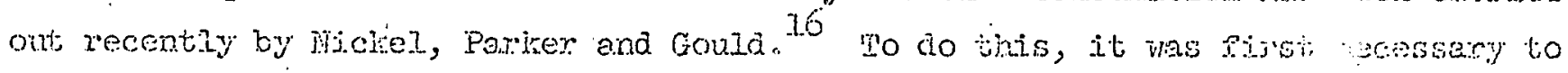
detemine the fom: of the electron aensity profile, $f$. This was done nunerical.-

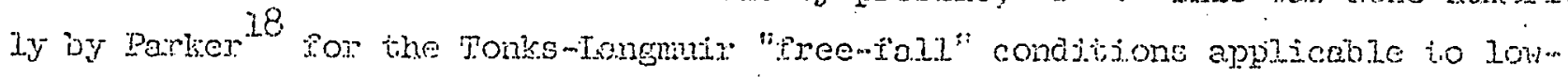

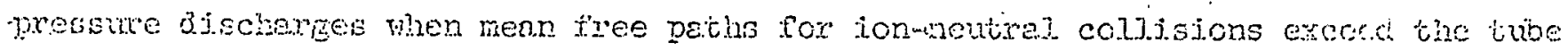
dinemsions.

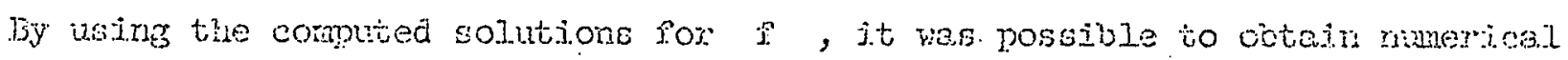
solutions to $\mathrm{Bg}$. (19) subject to the boundary condition of zero ladal electron. velooity; and contimuty of the logarithmic dexivetive of potential al the tho

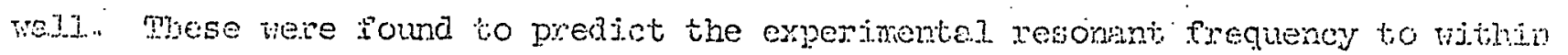
boot $10 \%$ conparison measurements of density veing mede by carity perturbation inethods. 16 similar accuracy has been obtained in comperisons with ripobe measute.

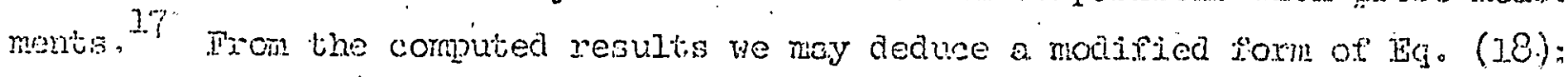

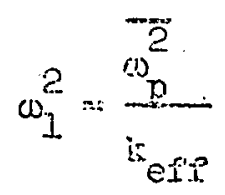




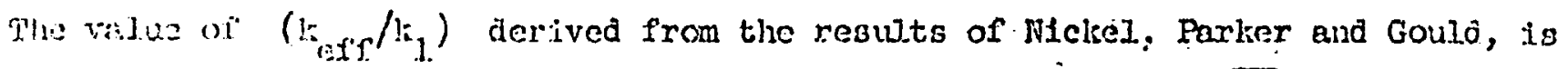
suiv in FiE. 7 plotted szainst the dimensionless paraieter $\left(d \sqrt{\lambda_{D}}\right)$, where $d$. if tix colum diancter and $\bar{\lambda}_{\mathrm{D}}$ is the electronic Debye length based on the mean electron density across the section. It lo clear that the veriational solution of Eq. (1.9) is good for $\left(a / \lambda_{D}\right)$ of the order of 200 or above. For lover valuer, a correction should be mende, based on e curve such as that of F1.E. 'T,' or an' improved trial function should be used in the veriationsi expression for the frequency. It should be noted that Fig. 7 la not a univerail curve, but has been given for one, typical, experimental value of $k_{1}$ only." 


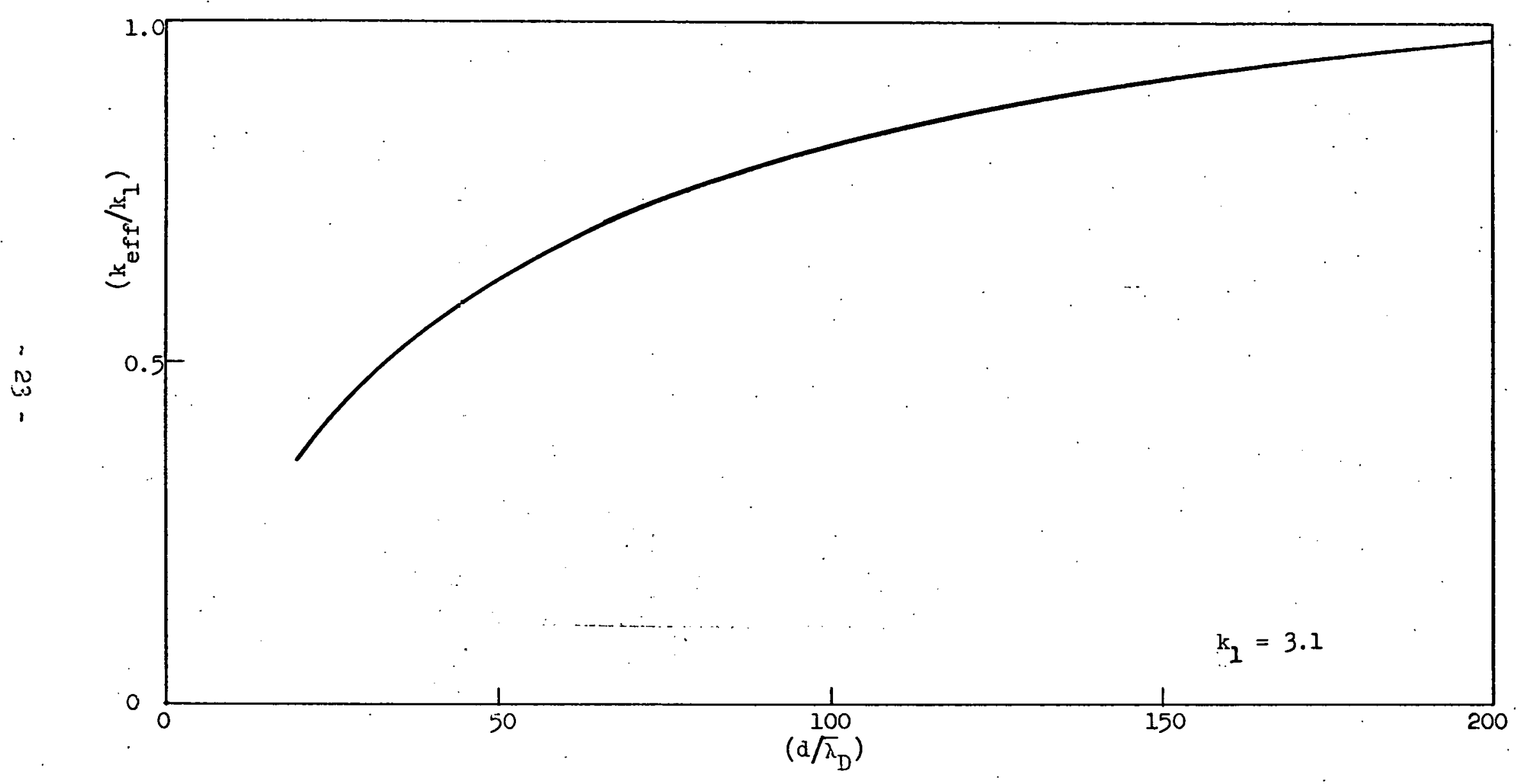

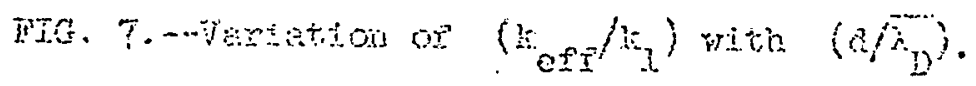




\section{III, THE EXETRINAWAL MTIEOD}

Wine tineries discuosed so Par cover the case of an infinitely lons discherge Whe, with no exial variationo of electron density, and contained within a concentric. jnfinitely long, netallic cylinder. A practical set-up is show in Iis. $8 \mathrm{a}$ in a form suitible for meosurine the axial variation of electron density along a discinirge columen.

\section{A. OBSTRYATIOATS ON RHSOMANCE SRAEE}

If the projortions of the exciting electrades are such thot their width is geater than theix. dianeter; a relatively cleen dipole resonance pent is weveliy observen with an experimental arrangement such as that shown in rig. Os. Hovever; the finite nature of the system allows longituljnally propagatinc modes to be excited Which ray shor up as indicated in Fig. ga. mhese can be efrectively suppressed by the use of the short-circulting xings shom in Tis. Ba. The sevarotion of twese is adjusted so as to minimize the subridingy peaks. By this method, strip-lines vith their wiouth equel to ing if their diemeter, or less, may be used rith lese than $5 \%$ erros in the resonance frequency measurements. 15

Then the spurious longitudinal proparation effects have been minimized, there

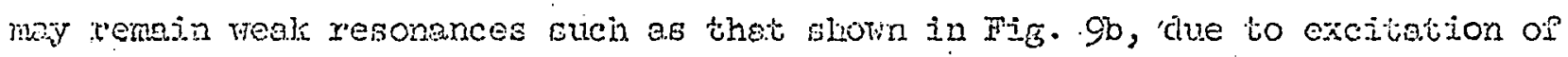
mitipole modes. These ray result from asymetry, or eccentricity of the tube, pilasma, or electrodes, and are nomilly of no importance.

A rurther jimportan series of resonances occurring at higher frequencies than that of the dipole mode is that first stoudied by Tonks in 1933, and wich was only recentiy been explained. 16, 17,19-2I Excitation or these resonances depends on the exictence of nonunifiox electron density and nonzero electron temperature. Thei: frequencjea say be predjcted from Eq. (I9). Since the dipole resonence is normally stronger and well sepajated from the first resonance in this subsialary sevief, there is no difficulty in recognizing it.

The $Q$ of the aipole resonance bas been rreajcted as (w/v) for an infinjtely Long sysiem. In prectiçe, somevhat lower values vill be obtalned due to losding by the externel cixcuit, and losses from the ends. The latter takes two forms; an 


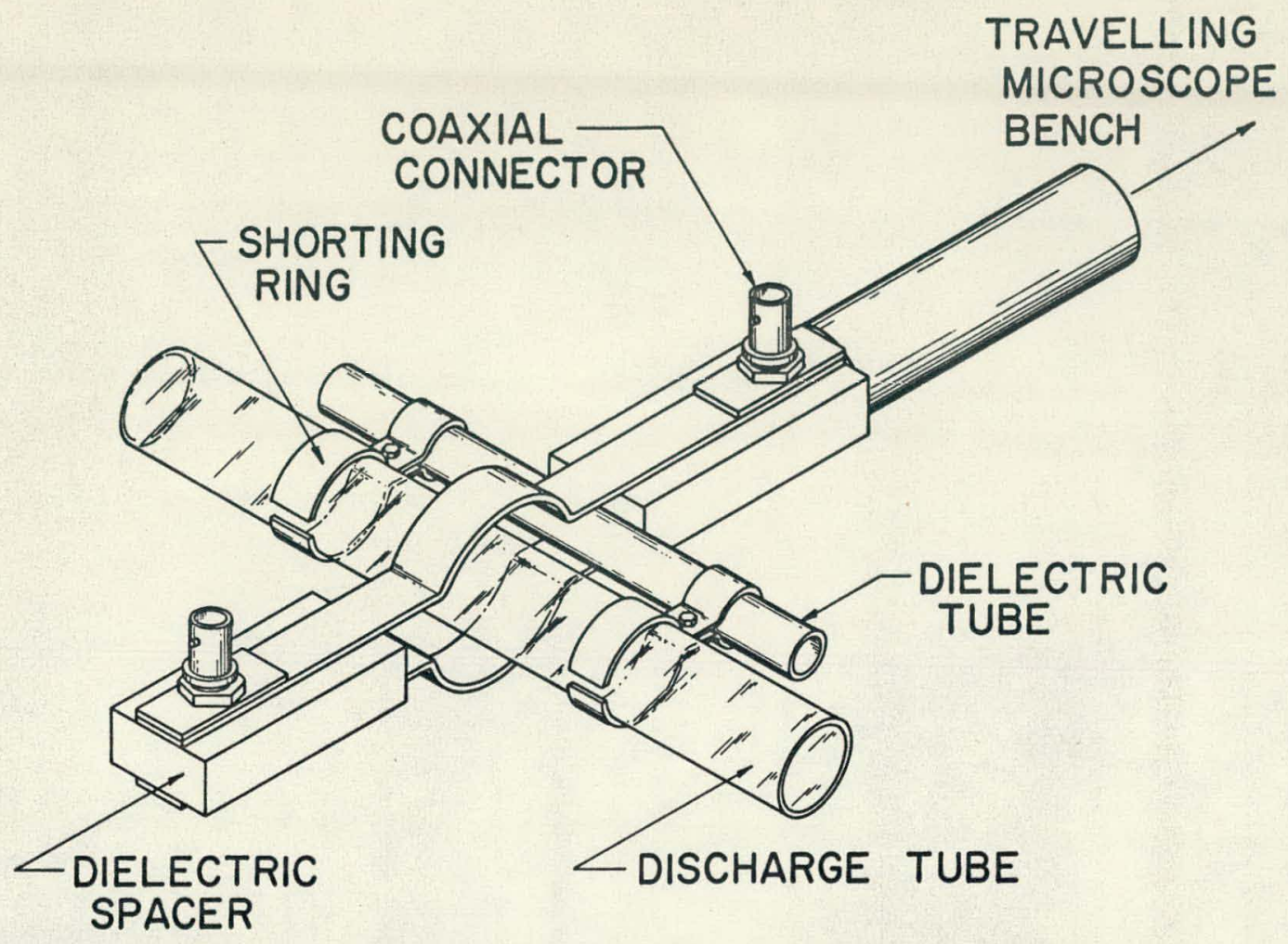

(a) STRIP - LINE GEOMETRY

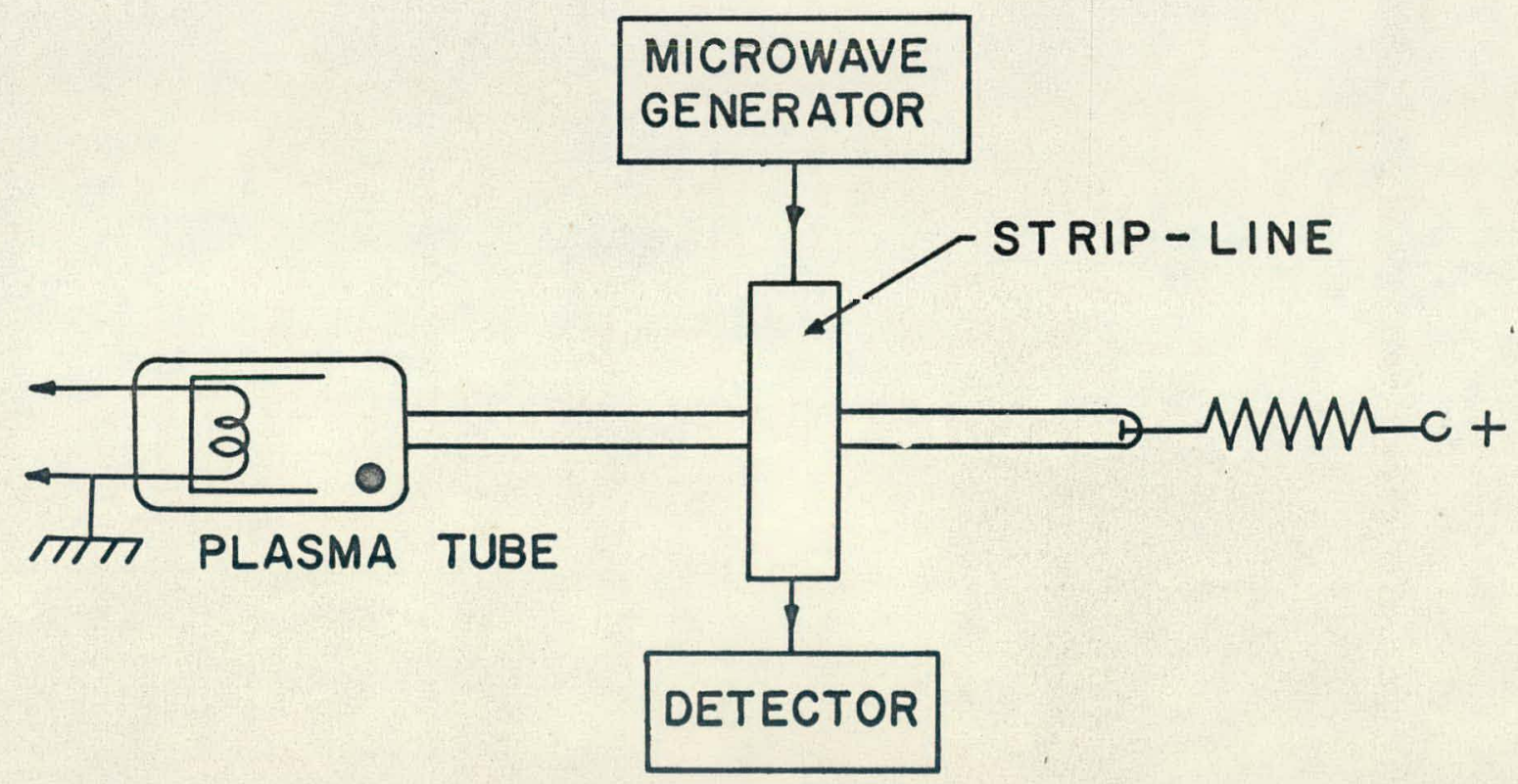

(b) SCHEMATIC CIRCUIT

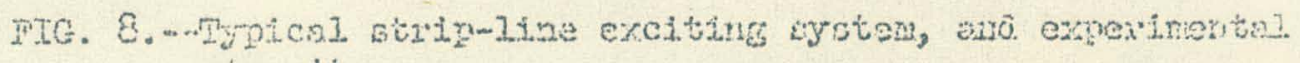
eicents. 


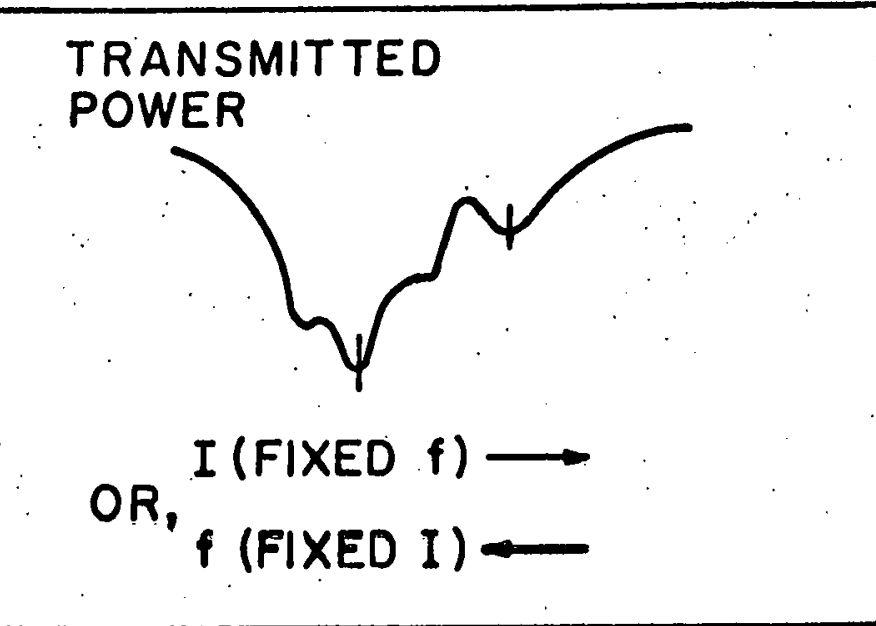

(a) WITHOUT SHORT-CIRCUITING RINGS

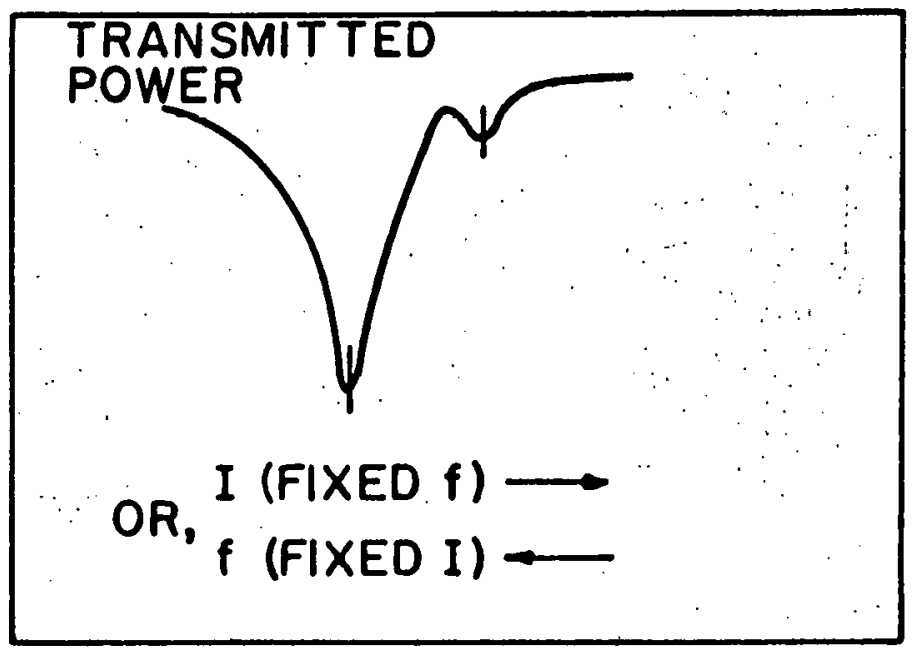

(b) WITH SHORT-CIRCUITING RINGS

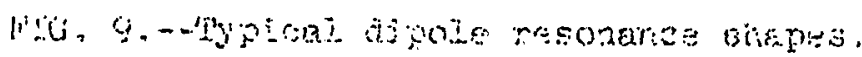




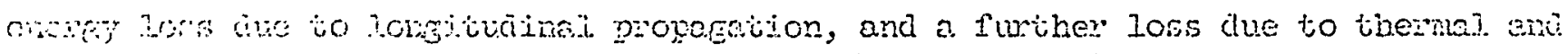

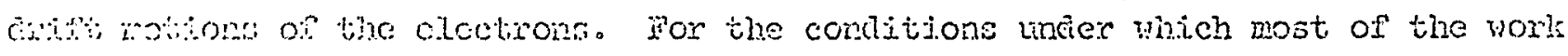

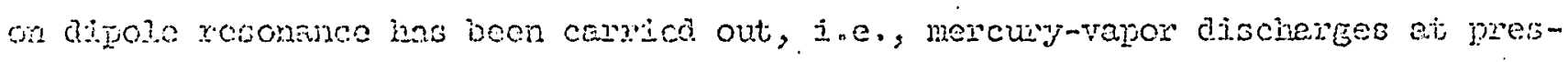
sures or ebow ly ry, these exfects corsine to give a a of betreen 10 and 100 .

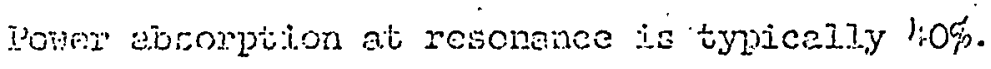

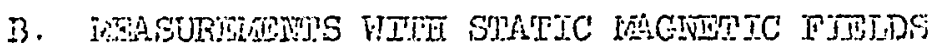

The experinentej evidence suggesta that for $\omega_{c}^{c}<\left(\omega_{1} / 2\right)$ theory and experingnt

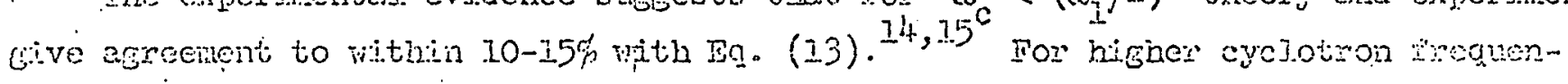
cies, honeres, one of the resonances disappess rapidiy. A possible axplanation fon this in thit the megnetic field hos a powentul effect on the electron density profile. At highex ragnetic piela strengths, the droop from the value on the axts inerases and for the reasons discussed earlier, the enaiysjs may becone invalid. The implica-

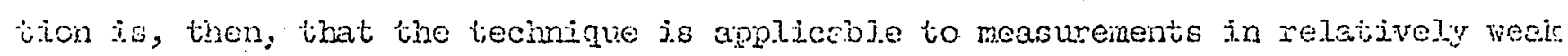
inogratic piejas.

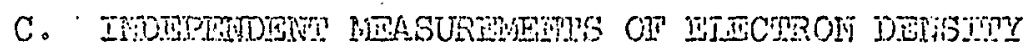

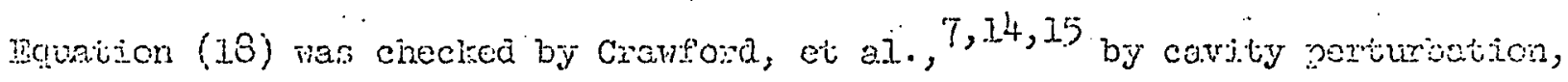
Iongitudinal jropagation, and Langmuir probe nethods. Agrectent; betboen conputied and neasmed dipole resonan frequencies was to within ebout zop, for ineasurencuts male witn and vithout an axiaj. waznetic field.

Fevetion (20) has been checked to within $10 \%$ by Gould; et al. 16 by reporenco

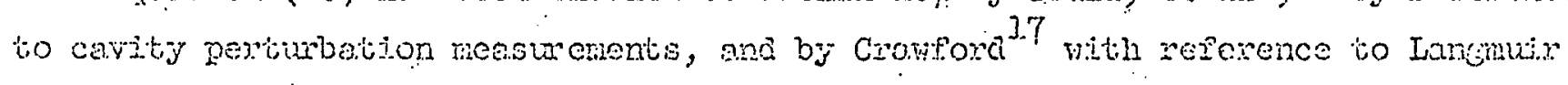
pacie manurements, vith no arial magnetic tield in either case.

\section{MTITPOTE IESOMUITES}

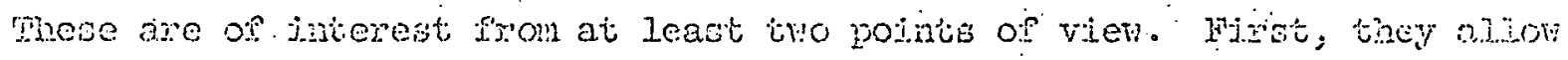

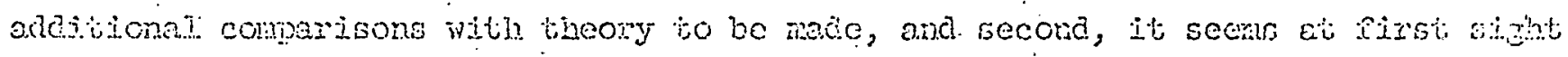

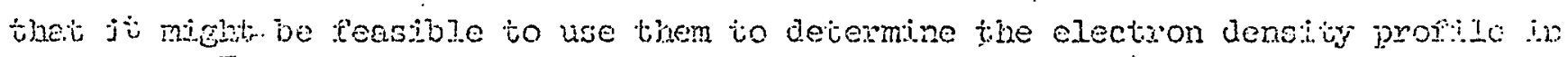

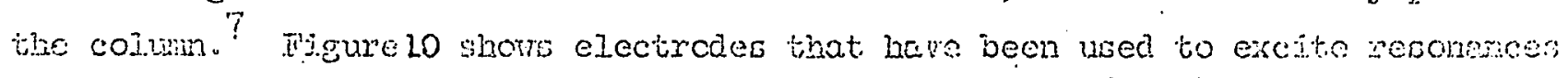
up to the octorole mode. In using these, cere mus be tolsen hot to emite aritione modes. Corefut balancing of the ni source is required to avoid buls. 


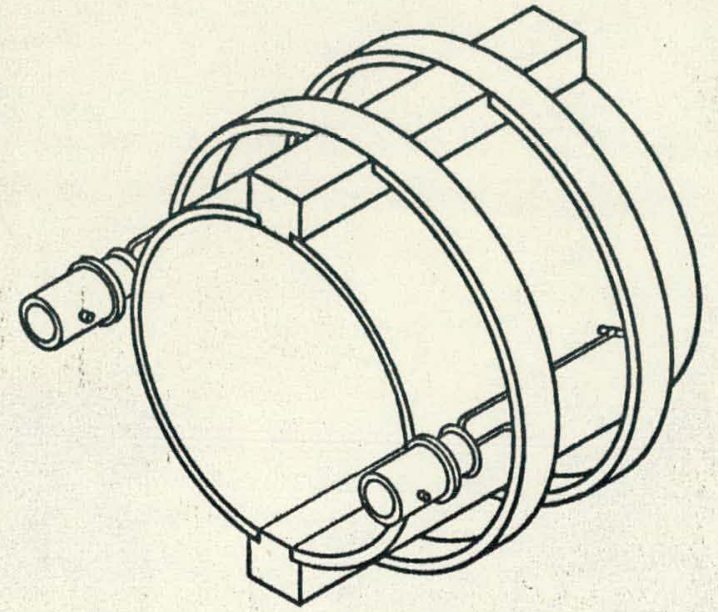

a) DIPOLE

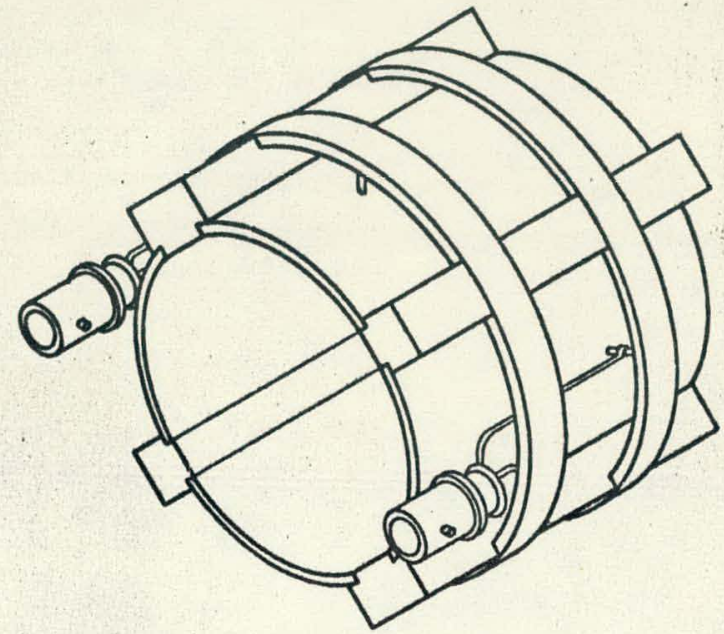

b) QUADRUPOLE

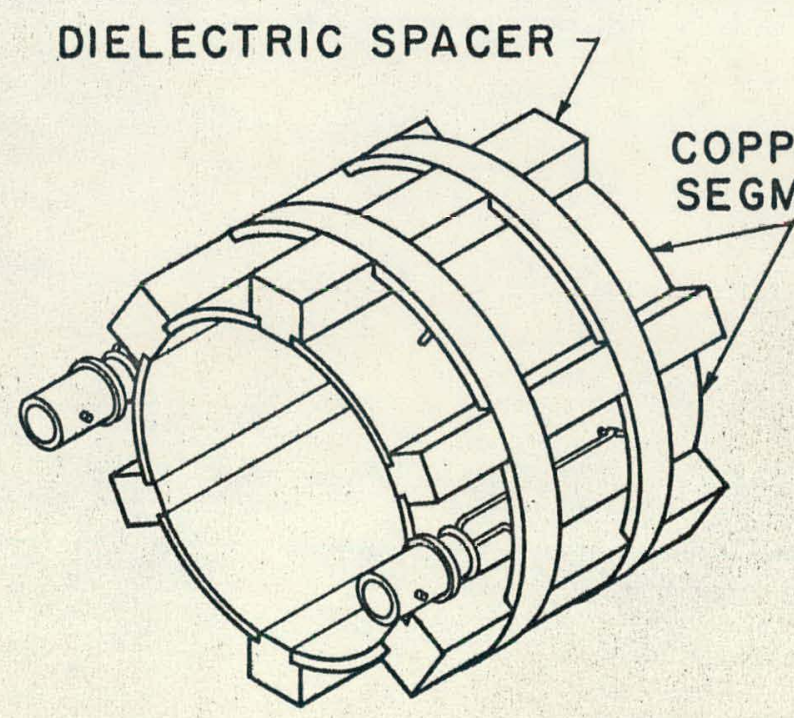

c) HEXAPOLE

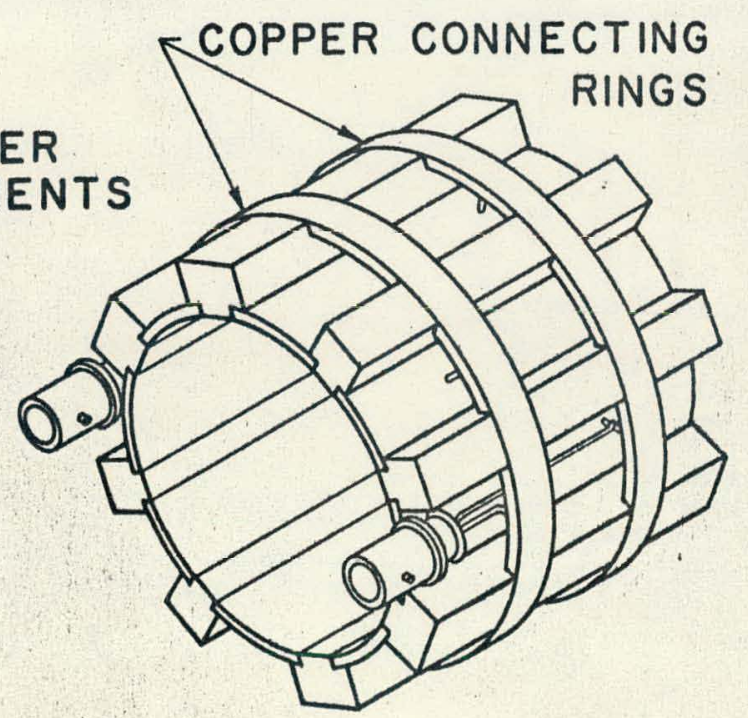

d) OCTOPOLE

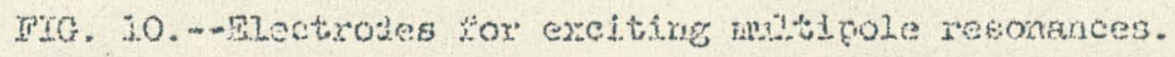




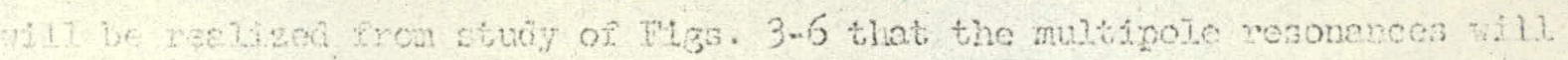
whely seperated maess the electroden fit closely round the discherge twhe

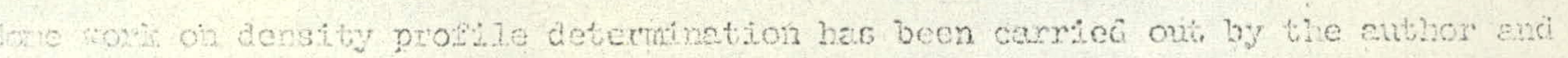

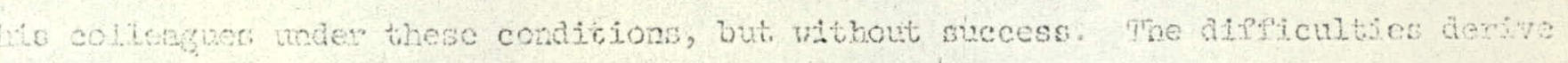
from the feet thet an expression of the form of $\mathrm{Eq}$. (17) is am exproxtration oniy. When these frequencies are manipulated algebraicany to deterinine the eleotron denbity prosile, horever, vory high accurecy is domonded if a reasonable resutt is to

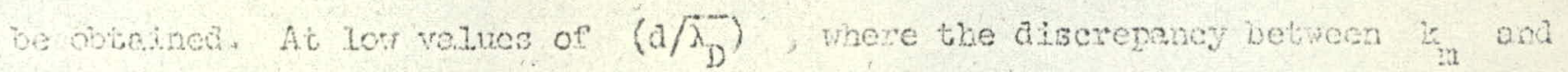

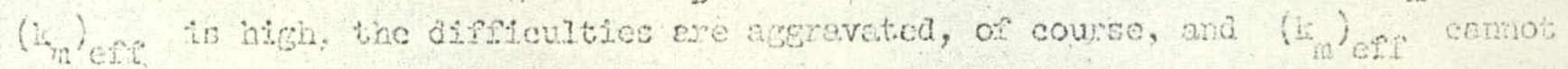

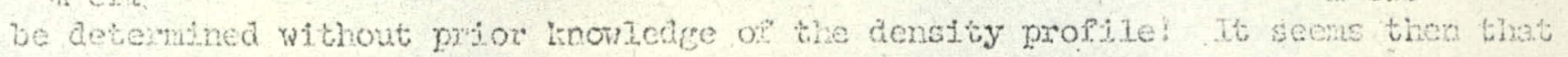
cecurece proftle determination by use of several modes will not be fenstble

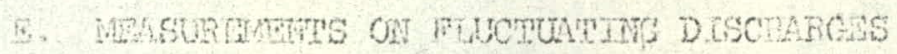

The ditole resonerse techique hes beon applied to the study of eluctuathes digeherges havine electron densty flucturtion anditudes of the order of a fen

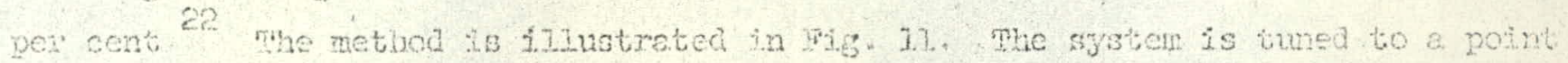

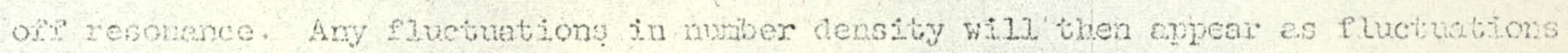

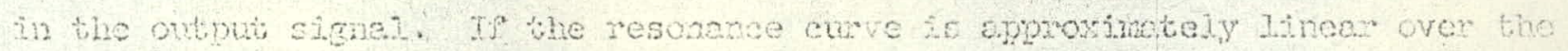

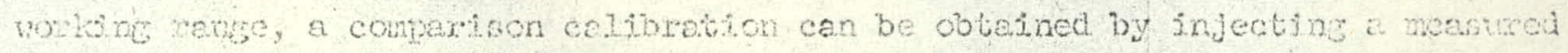
sinuootad conponont of cumont, at a frequepey belov about $\mathrm{I} \mathrm{ke} / \mathrm{s}$, and not ing the corregponting output sigaal. The colloration th then given by

$$
\frac{n_{e c}}{n_{d e}}=\frac{I_{d c}}{I_{d c}}
$$

where ho is calculated from the dipolo resonent froquency, and no conespowks, to the measured ouput oignel.

A Though the frequency sensitivity of the dyole resonance is aboth, tw oncers

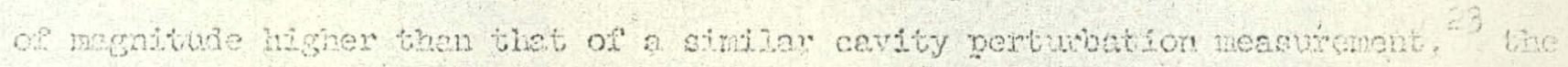
owhot seneltivity in not. This factos depends on the 0 of the renononce which is an ordor of naghtude Ioner for the dipole zegonance system. There jo stit, hovever, e swbsanthally higher output fron the dipole nesonance systen 


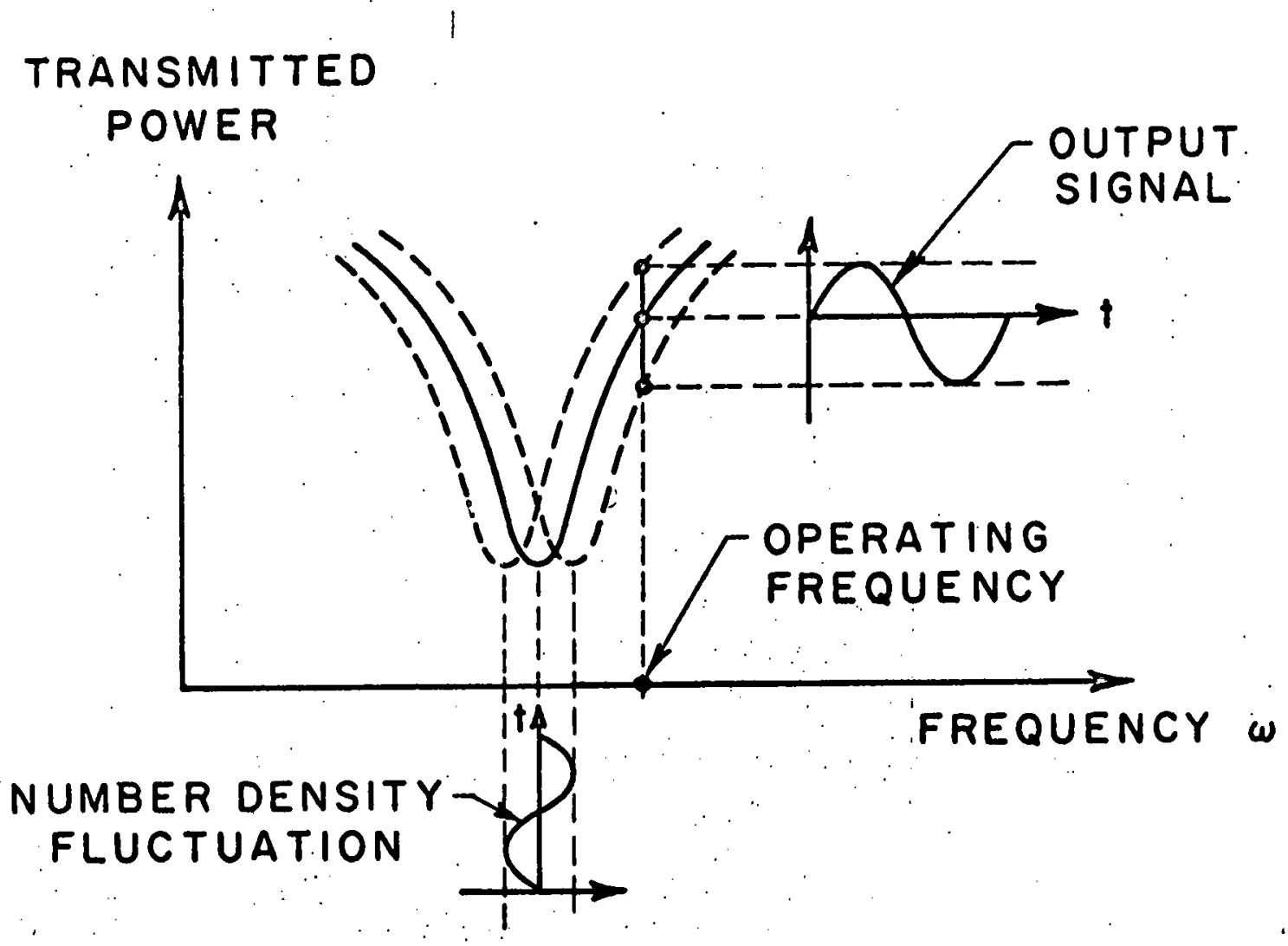

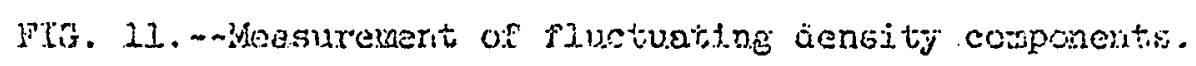




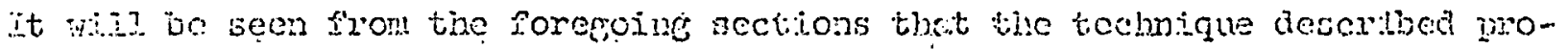

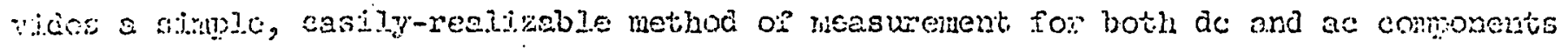

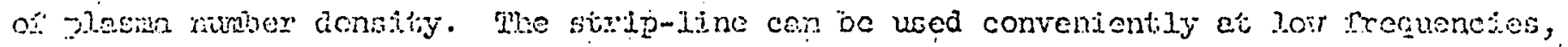

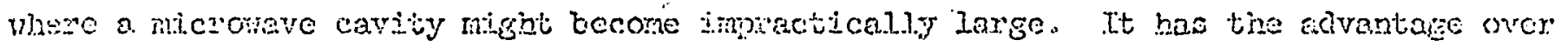
properation measmenents that ths egatial. asolution is high, rerticulerly when

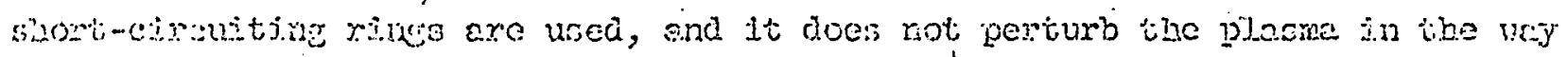
tirat re or Langmuir proves niej.

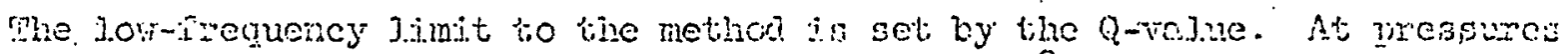

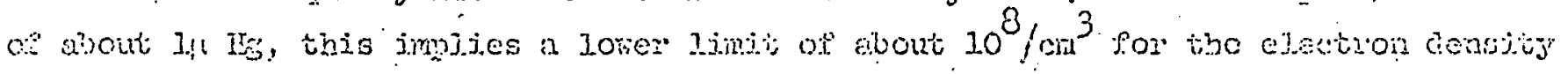

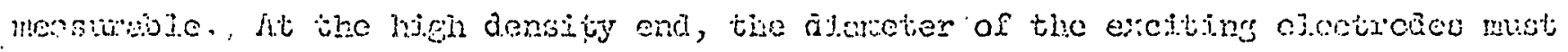

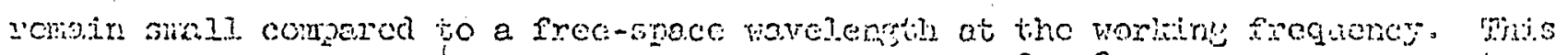

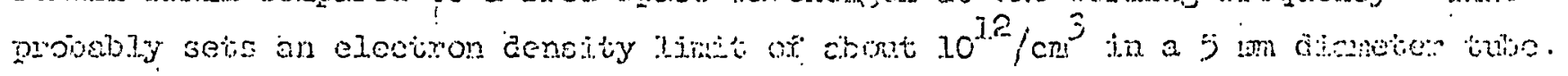

A nuiber or ponsible derelomeats still remin to be eranine?. Fon cromino.

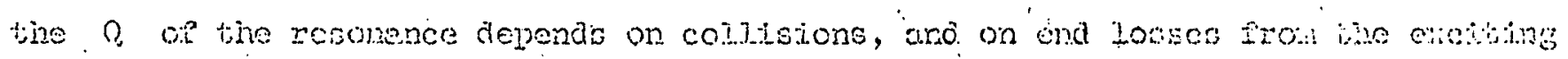

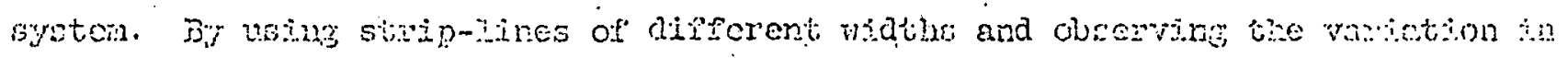

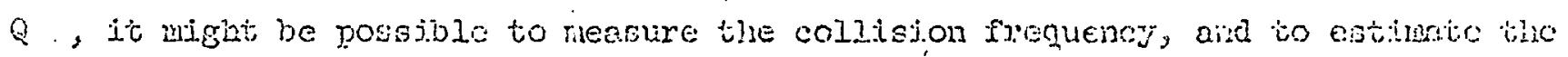

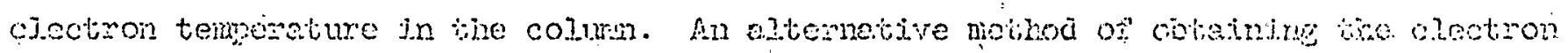

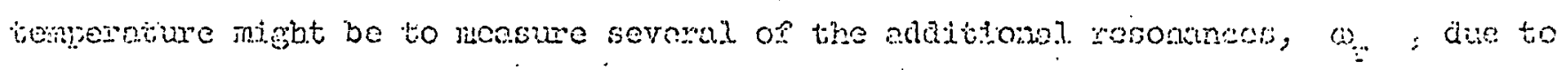

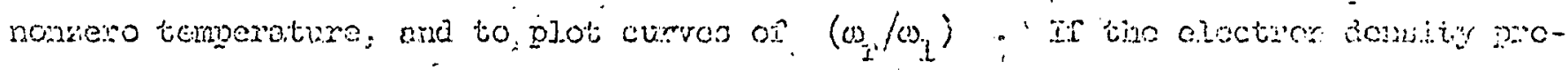

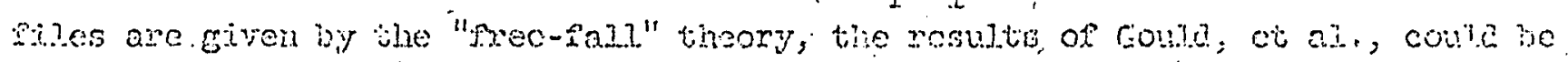
comprea vith those to give on esturiats of the election iemperotur. 


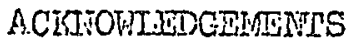

The tochique described has been deveioped over a period of screral years. During this time, major contributions bave been mode by Dr. G. S. Kino, and S. A. Selit, ard considerable assistance hos been eiven by Dr. J, Spatier, $A$. B. Camera and $G$. it. Hagrsquist. The vorls was supporied by the U. S. Atomic Inergy Commiston. 


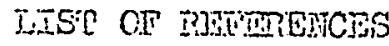

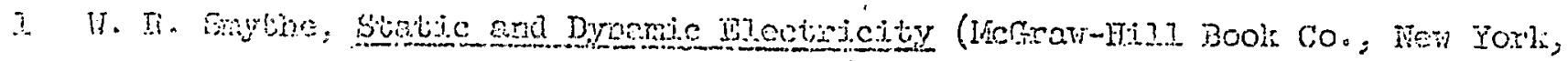
1950), (200 sa., 21) 65-69.

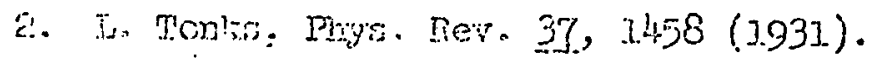

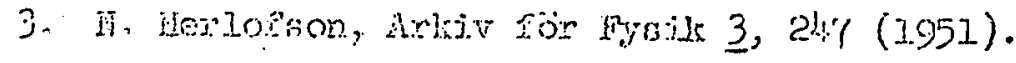

4. A. Mobror, Wricoson Iechnies 8, 1. (1963).

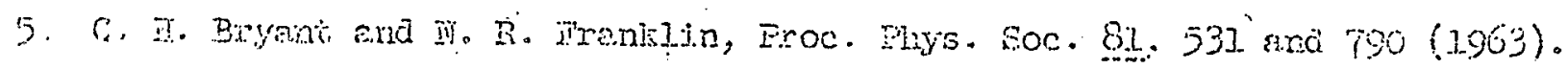

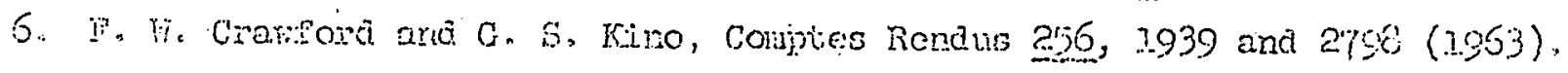

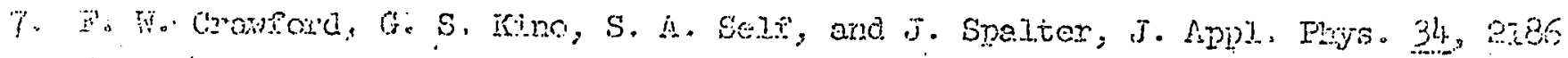
$(1.963)^{\circ}$

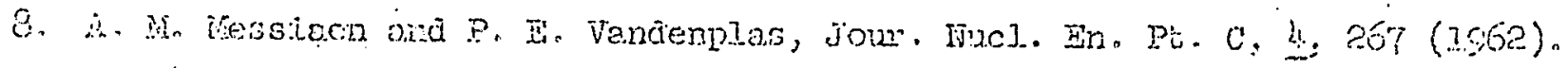

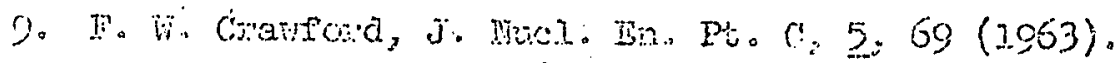

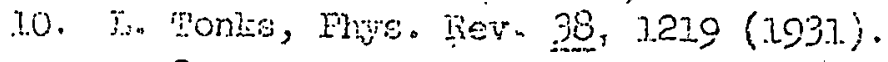

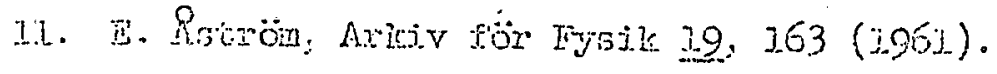

12. A. Dotinex, Fricsson Meclinjes 2.309 (1957).

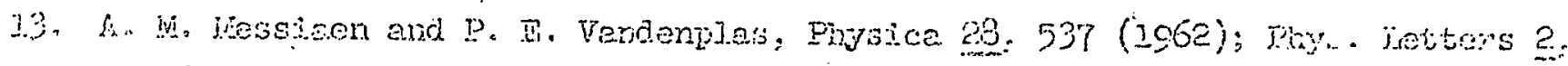
103 (2962).

14.

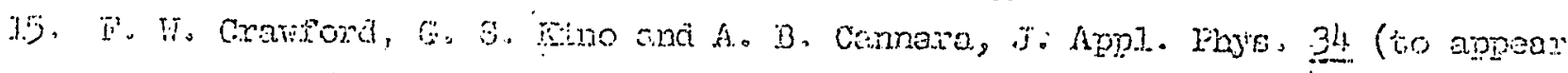
Irovemer 1963 ).

16. J. C. Michei, a. V. Prien ond R. W. Cond, Mys. Rer. Lettera 1], 183 (1963).

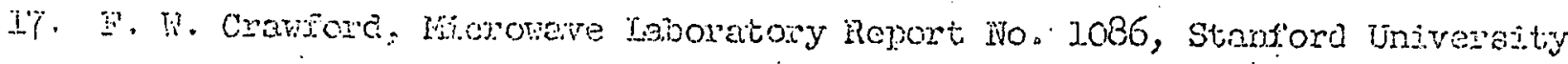
(Septenber 1963).

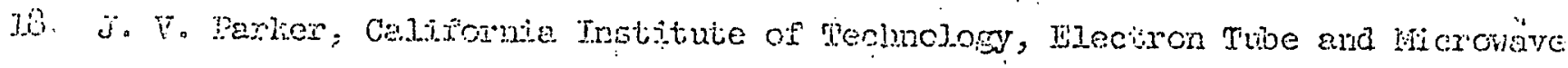

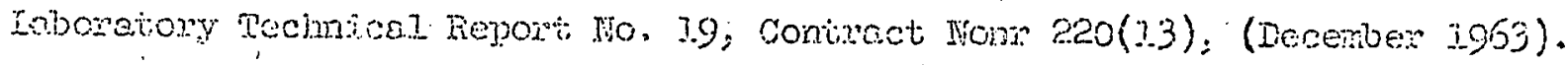

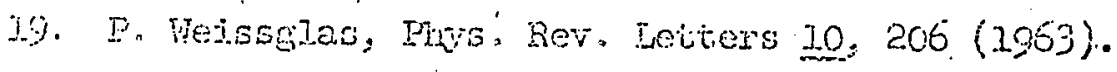

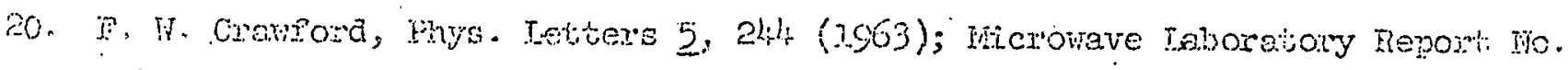

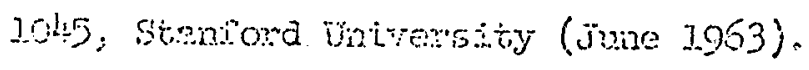

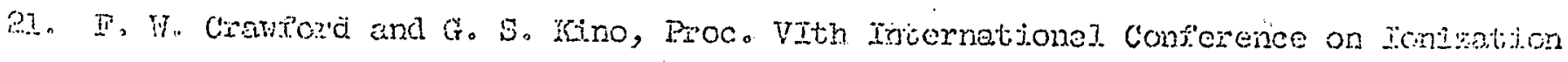
Enenonens in esser, Paris (Juiy 1963) (in press).

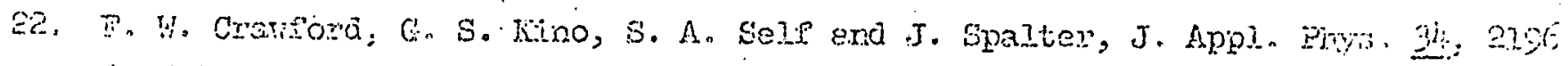
$(1.963)$

23. T. W. Crewfond and J. D. Temson, j. Mucl. En. Ft. C, 3, 179 (196i). 